\title{
Concepción de Marketing para la apertura de una firma productora de Inoculantes para Soja
}

Trabajo Científico libre para la obtención del grado de Magister en Marketing Internacional de la Escuela de Postgrado de Marketing Internacional -Facultad de Ciencias Económicas

- Universidad Nacional de La Plata -

Profesor Director de Tesis: $\quad$ Presentado por:

Prof. Ing. Enzo Campana Lisandro Menéndez Paratore

Calle $55 \mathrm{~N}^{\circ} 866$, piso 10

(1900) La Plata

Fecha de entrega: 03-05-2011 


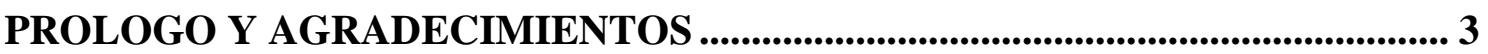

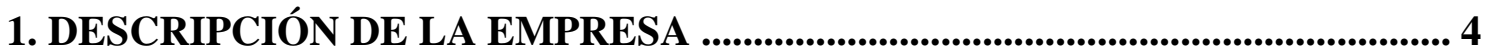

1.1 Introducción ......................................................................................................................................

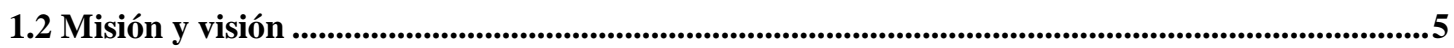

2. MACROAMBIENTE EN EL QUE SE DESEMPEÑARÁ LA FIRMA ................ 6

2.1 Contexto Macroeconómico ……….....................................................................................6

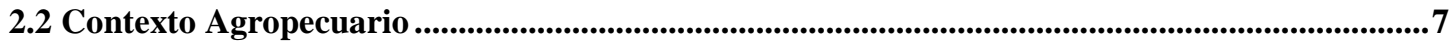

2.3 Contexto específico: el cultivo de soja..........................................................................................

3. MICROAMBIENTE EN EL QUE SE DESEMPEÑARÁ LA FIRMA................ 11

3.1 Competencia en el negocio de insumos agropecuario...........................................................11

3.2 Análisis de la competencia en el mercado de inoculantes...........................................................11

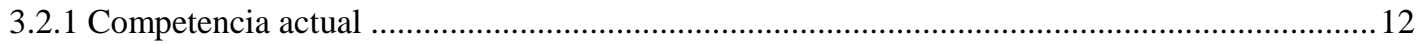

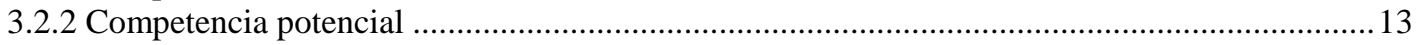

3.2.3 Análisis de los competidores actuales y potenciales (Players) ............................................ 14

3.3 Perfil de los consumidores de inoculantes .................................................................................19

3.3.1 Características del consumidor típico ..............................................................................19

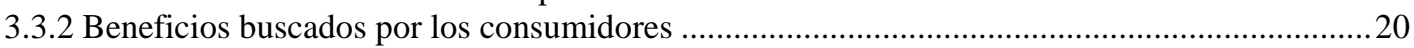

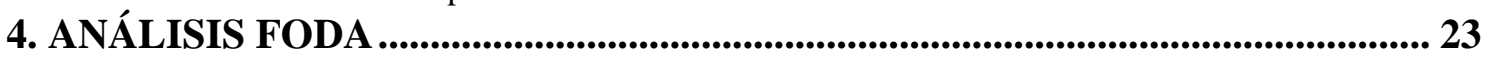

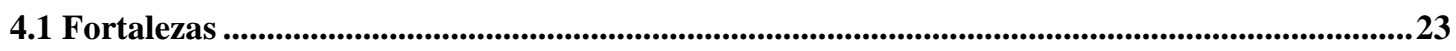

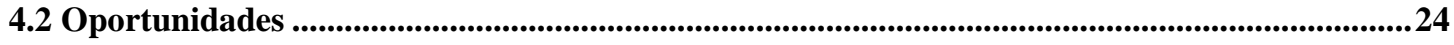

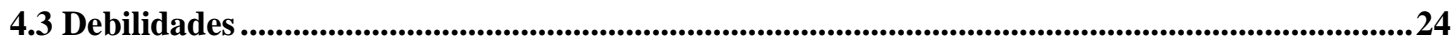

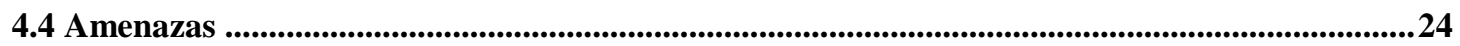

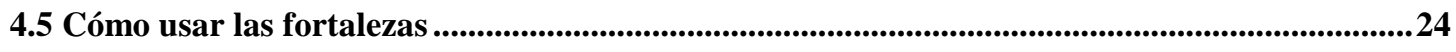

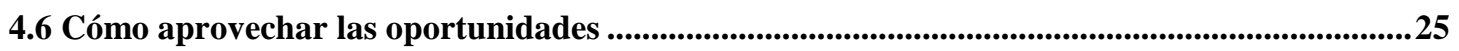

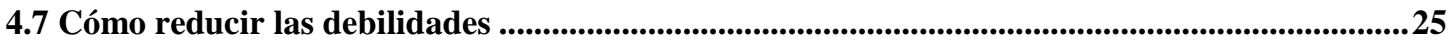

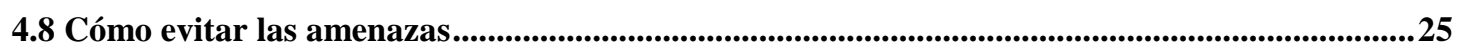

5. SEGMENTACIÓN Y POSICIONAMIENTO_...................................................... 26

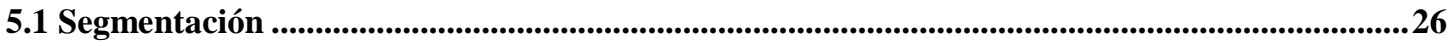

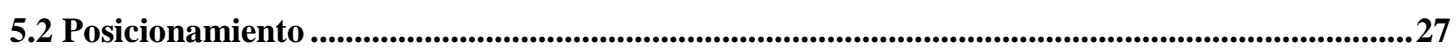

6. ESTRATEGIA DE MARKETING MIX DE AGROINVEST ............................ 30

6.1 Estrategia de Producto en la Etapa de Introducción................................................................31

6.2 Estrategia de Precio en la Etapa de Introducción.............................................................................35

6.3 Estrategia de Distribución en la Etapa de Introducción ..........................................................36

6.4 Estrategia de Comunicación y Promoción en la Etapa de Introducción ......................................38

7. MERCADO POTENCIAL ................................................................................... 40

7.1 Mercado actual de inoculantes en el segmento objetivo .........................................................40

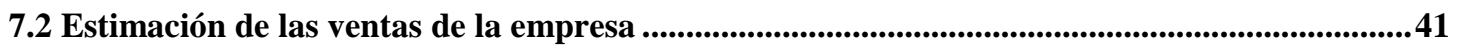

8. FLUJO DE FONDOS DE AGROINVEST ...................................................... 43

9. SITUACIÓN ACTUAL DE LA EMPRESA ....................................................... 46

10. BIBLIOGRAFÍ'A ................................................................................................... 48

11. $\mathrm{ANEXO}$.................................................................................................................... 50 


\section{PRÓLOGO Y AGRADECIMIENTOS}

La elaboración de esta Tesis tuvo como principal objetivo, generar las condiciones propicias para el desarrollo de un proyecto de producción de inoculante para soja presentado en el marco del Programa Incubadora de Empresas ofrecido por la Agencia de Desarrollo de la Municipalidad de Junín en el año 2001. Asimismo, este trabajo prosiguió su camino hasta conseguir inversores que pudieran aportar los fondos necesarios para el start-up del negocio. En 2003, se consiguió dicho objetivo con lo cual gran parte de la información contenida en el estudio es la existente en ese momento.

A partir de la asistencia brindada por este estudio, a finales del año 2001 fue posible conseguir un predio otorgado por el Programa de Incubadora de Empresas mencionado anteriormente, para producir inoculantes para soja. La aprobación del proyecto, coincidió con el detonante de la peor crisis económica del país. A pesar de los innumerables inconvenientes que fueron retrasando la puesta en marcha del negocio (falta de financiamiento, adecuación de la planta a las necesidades de la firma, etc.) la voluntad y perseverancia de los socios hizo posible la concreción del proyecto.

A mediados del año 2003, se consiguió el financiamiento necesario para iniciar el proyecto en una planta de $100 \mathrm{~m} 2$ localizada en el Parque Industrial Junín. Al año siguiente se realizaron las inscripciones de la sociedad en los organismos competentes: Dirección de Personas Jurídicas de la Provincia de Buenos Aires, AFIP, SENASA, etc. Luego de 4 años de presencia en el mercado, en el año 2008 se adquirió un predio de una hectárea en el mismo Parque y se construyó una planta de $900 \mathrm{~m} 2$ con capacidad para la producción de 4.000.000 de dosis de inoculante. Actualmente la empresa tiene una importante presencia en el mercado nacional y exporta parte de su producción a Paraguay y Bolivia y próximamente se prevé incursionar en el mercado brasileño.

En cuanto a los agradecimientos, el primer lugar lo ocupan mi familia por haberme apoyado incondicionalmente en todo momento. Más allá de felicitar a los dos socios, Javier Bilos y Juan Francisco Menéndez, por su perseverancia y su decisión de invertir en el país en un momento muy difícil, quiero agradecerles la posibilidad que me brindaron para realizar este trabajo; además de la confianza que depositaron en mi en todo momento.

Por otra parte, no quiero dejar de agradecer a las autoridades del Ministerio de Economía de la Provincia de Buenos Aires, principalmente al Lic. Eduardo Cerimedo, por haberme ofrecido la posibilidad de continuar con mi formación en este prestigioso Magister.

Por último, pero no por ello menos importante, quiero manifestar mi agradecimiento a 3 personas directamente vinculadas a esta Tesis. A mis Directores, el Lic. Aníbal Cueto, por sus muy valiosos comentarios y sugerencias durante buena parte de la elaboración de este trabajo y al Ing. Enzo Campana, quién fue un artífice muy importante en la etapa final del estudio y quién me motivó para finalizar este trabajo. Y a la Secretaria Académica del Magister, Lic. Liesel Bischoff, por su constante preocupación, ocupación y amabilidad demostrada a lo largo de toda la carrera. 


\section{DESCRIPCIÓN DE LA EMPRESA}

\subsection{Introducción}

El vertiginoso crecimiento de la actividad agropecuaria en la región pampeana argentina en los últimos años motivó un estudio acerca de la posibilidad de incursionar en la provisión de algún tipo de insumo utilizado por el sector. El cultivo de soja, se ha destacado respecto al resto favorecido por el incremento de su precio internacional. A partir de este fenómeno surgió la idea de proveer insumos para la siembra de esta oleaginosa, específicamente inoculantes para soja.

El Ing. Agronómo brasileño, Solon C. De Araujo define a un inoculante "como todo producto a base de microrganismos, capaz de favorecer el desarrollo de las plantas”. Más específicamente, los inoculantes para leguminosas (como la soja) tienen como base bacterias tales como Rhizobium e Bradyrhizobium y su función es utilizar el nitrógeno de la atmósfera para producir compuestos nitrogenados utilizando como fuente de energía los carbohidratos aportados por las plantas, proceso denominado Fijación Biológica del Nitrógeno.

El proyecto original comenzó a tomar forma a mediados del año 2001, una vez que la Municipalidad de Junín, a través de su Agencia de Desarrollo, presentó el Programa Incubadora de Empresas destinado a emprendedores con ideas productivas e innovadoras. Esta agencia, otorgaba ciertos beneficios a los proyectos seleccionados. Entre ellos se destacan: ${ }^{2}$

$\checkmark$ Uso de instalaciones y/o servicios por el plazo renovable de un año

$\checkmark$ Disponibilidad de una planta de hasta 100 metros cuadrados cubiertos para desarrollar la actividad

$\checkmark$ Apoyo y asistencia en asesoramiento económico-financiero; formación en sistemas de comercialización, marketing y publicidad.

Se presentaron en tiempo y forma todos los requerimientos exigidos y se obtuvo el logro buscado a fines del año 2001. Las turbulencias económicas que afectaron a nuestro país impidieron la puesta en marcha del proyecto ya que no fue posible acceder a fuentes de financiamiento necesarias para comenzar el emprendimiento.

Durante todo el año 2002 se comenzaron a establecer contactos con potenciales socios debido a las restricciones que se enfrentaban en el mercado crediticio. A fines de dicho año, se decidió incluir en la sociedad a un Ingeniero Agrónomo que administra un pool de siembra, quien se mostró interesado en participar en el negocio. Durante el año 2003, se cumplimentó el equipamiento de la planta industrial, realizando un cúmulo de inversiones periódicas hasta llegar a una planta con capacidad para producir aproximadamente 12.000 litros de inoculantes por año. Para la siembra de la campaña 2004-2005 se comenzó a vender el producto Fullbacter en pequeña escala a productores

\footnotetext{
${ }^{1}$ Araujo (2001).

${ }^{2}$ Los mismos fueron extraídos de los folletos confeccionados por la Agencia de Desarrollo Junín.
} 
de la zona mientras se avanzaba en la aprobación de la sociedad en el Registro Provincial de Propiedad Industrial y en la habilitación del laboratorio en el SENASA.

A lo largo de los años, Fullbacter ha ido en constante crecimiento en la consideración de los productores agrícolas como así también en los principales distribuidores de agroinsumos. En este sentido, es destacable que el principal vendedor de inoculantes sin planta propia del país (Facyt SA) decidió adquirir a fasón Fullbacter y venderlo con marca propia en un segmento de inoculantes Premium, reconociendo los elevados estándares de calidad del producto. ${ }^{3}$ Por otra parte, la estación INTA Castelar (ente oficial y órgano rector en materia de innovación tecnológica en el agro argentino) valora la calidad del producto a partir de los controles que realiza. Todo esto ha posicionado a Fullbacter dentro de los inoculantes denominados Premium en Argentina.

\subsection{Misión y visión}

La misión de un negocio es entendida como la definición del mismo, es decir indica a qué se dedicará la empresa pero no las herramientas que se van a utilizar para llegar a ese fin. En el caso particular de la firma en estudio, la misión será:

"Elaborar productos microbiológicos de alta calidad y rendimiento, desarrollados bajo normas internacionales de manufactura”

En este sentido, AgroInvest tiene asumido el compromiso de lograr, permanentemente, la máxima satisfacción del Cliente, no sólo a través de la comercialización de productos desarrollados siguiendo los mayores estándares de calidad, sino también brindando un servicio integral que complete su oferta.

La producción está avalada por las buenas prácticas de manufactura y los departamentos de control de calidad. Asegurando el transporte de mercadería en forma y tiempo por medio de una moderna flota de camiones.

En el caso particular de la empresa en estudio, la visión pensada en un lapso de diez años es la siguiente:

“Alcanzar y sostener una posición de privilegio en investigación, desarrollo y comercialización de productos microbiológicos de excelente calidad que compitan a nivel mundial”.

Para ello se previó crear nuevas modalidades de comercialización: Alianzas estratégicas con empresas distribuidoras de agroinsumos para comercializar productos con marca propia, haciendo cesiones de producto (elaboración a Fason) y dando la posibilidad a canje por agroinsumos para satisfacer la amplia demanda que requiere el mercado.

\footnotetext{
${ }^{3}$ La firma Facyt en el año 2009 finalizó su propia planta y comenzó a producir su propio inoculante, dejando de adquirir el producto Fullbacter.
} 


\section{MACROAMBIENTE EN EL QUE SE DESEMPEÑARÁ LA FIRMA}

\subsection{Contexto Macroeconómico}

La economía argentina ha atravesado por diversas fases de crecimiento combinadas con caídas bruscas del producto a lo largo de su historia. Durante la década del '80, considerada la década perdida en toda Latinoamérica, la economía argentina no fue la excepción al estancamiento económico evidenciado en toda la región.

Desde comienzos de los años '90, se implementaron una serie de reformas económicas, siguiendo las tendencias mundiales de liberalización que incluyó privatizaciones, desregulación de distintos mercados, apertura de la economía junto a la fijación del tipo de cambio nominal, iniciando así el denominado Plan de Convertibilidad. Uno de los principales objetivos de este cambio de rumbo fue controlar uno de los principales flagelos existentes en ese momento: los elevados niveles de inflación.

La política implementada tuvo éxito en su principal objetivo y, a su vez, posibilitó un acelerado crecimiento económico durante los primeros años de la década del ’90 (ver Gráfico Nº 1).

\section{GRAFICO $\mathbf{N}^{\circ} 1$ \\ EVOLUCIÓN DEL PIB ARGENTINO}

(I trim. 1980=100)

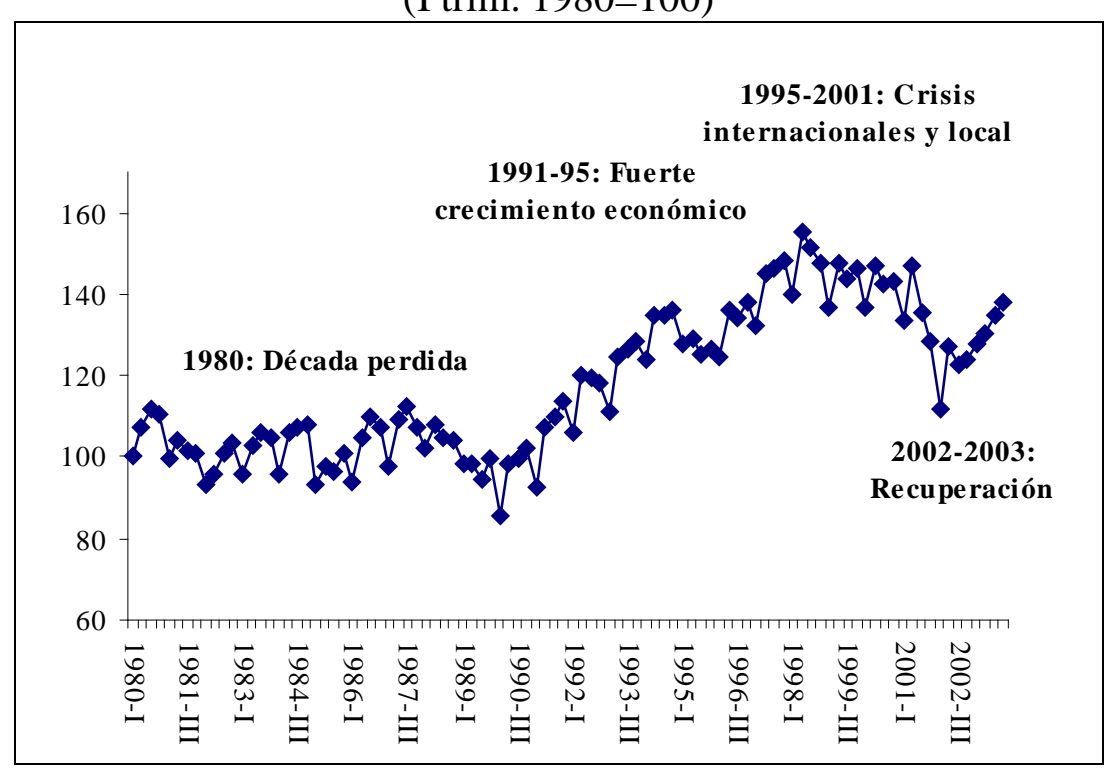

Fuente: elaboración propia en base a INDEC.

Sucesivas crisis financieras internacionales iniciadas con la devaluación de la moneda mexicana a fines de 1994, continuando con la crisis rusa en 1998 y la brasileña en 1999 junto a problemas políticos y económicos internos condujeron a una de las peores crisis económicas argentina a lo largo de su historia.

A finales de la década del '90, la economía doméstica comenzó a transitar un proceso de ajuste recesivo que, entre otros factores, respondía al debilitamiento de las posibilidades de competir exitosamente en los mercados externos.

El abandono del régimen cambiario a comienzos de 2002 marca el inicio de una nueva etapa, a partir de la cual las condiciones macroeconómicas resultan favorables 
para los complejos industriales. En otros términos, el cambio "ventajoso" de los precios relativos, sumado al desarrollo que tuvieron diversas áreas manufactureras en la década anterior, confluyen en un nuevo escenario futuro, donde no sólo resultan mayores los beneficios potenciales para los sectores que mayor dinamismo mostraron la década anterior, sino también para el resto.

\subsection{Contexto Agropecuario}

El sector agropecuario argentino ha sido históricamente uno de los principales generadores de divisas para el país. Los cuatro principales cultivos producidos en nuestro país han sido históricamente el maíz, el trigo (cereales), la soja y el girasol (oleaginosas).

Durante la década del '80, el maíz y el trigo se disputaban el primer lugar en términos de volúmenes producidos. Ya a partir de la década del '90 y con más fuerzas desde fines de dicho decenio, la soja comenzó a ser el principal cultivo argentino (ver cuadro siguiente).

\section{CUADRO $\mathrm{N}^{\circ} 1$ \\ PRINCIPALES CULTIVOS ARGENTINOS}

(Década del '80 y del '90)

\begin{tabular}{|c|c|cccc|c|}
\hline Cultivo & $\begin{array}{c}\text { Millones de } \\
\text { Tn producidas } \\
(1979-80)\end{array}$ & $\begin{array}{c}\text { Toneladas } \\
\text { producidas } \\
(1985-86)\end{array}$ & $\begin{array}{c}\text { Toneladas } \\
\text { producidas } \\
(1990-91)\end{array}$ & $\begin{array}{c}\text { Toneladas } \\
\text { producidas } \\
(1995-96)\end{array}$ & $\begin{array}{c}\text { Toneladas } \\
\text { producidas } \\
(2002-03)\end{array}$ & $\begin{array}{c}\text { Toneladas } \\
\text { producidas } \\
(2007-08)\end{array}$ \\
\hline Soja & 3.5 & 7.1 & 10.9 & 12.4 & 34.8 & 45.3 \\
Maíz & 6.4 & 12.1 & 7.7 & 10.5 & 15.0 & 20.4 \\
Trigo & 8.1 & 8.7 & 11.0 & 9.4 & 12.3 & 14.5 \\
$\begin{array}{c}\text { Girasol } \\
\text { \% soja }\end{array}$ & 1.65 & 4.1 & 4.0 & 5.6 & 3.7 & 4.5 \\
sobre total & $\mathbf{1 7 , 8 \%}$ & $\mathbf{2 2 , 2 \%}$ & $\mathbf{3 2 , 4 \%}$ & $\mathbf{3 2 , 8 \%}$ & $\mathbf{5 2 , 9 \%}$ & $\mathbf{5 3 , 5 \%}$ \\
\hline
\end{tabular}

Fuente: elaboración propia en base a Secretaría de Agricultura Ganadería, Pesca y Alimentación (SAGPyA).

El nuevo contexto económico tras la devaluación del peso argentino, favoreció notoriamente la expansión del sector agropecuario que además fue beneficiado de la suba de los precios internacionales. No obstante ello, la rentabilidad del sector se vio erosionada por la introducción de derechos de exportación (retenciones) que habían dejado de existir a comienzos de la década del '90. A pesar de los niveles de retenciones actuales el agro argentino continúa siendo muy competitivo y la rentabilidad del sector permanece en niveles históricos elevados.

A su vez han existido otros factores que han motivado una expansión del sector agropecuario en los últimos años tales como el avance de la siembra directa, práctica que se ha difundido rápidamente en los cultivos durante los últimos años y forma parte del paquete tecnológico impulsado por las empresas transnacionales de semillas y agroquímicos. Se trata de una modalidad de siembra que se realiza sobre el rastrojo del cultivo anterior, de modo que no requiere la preparación previa del suelo, lo cual disminuye drásticamente los costos en maquinarias asociados a la siembra tradicional. Al mismo tiempo, reduce los problemas de erosión y compactación de los suelos. Esta técnica productiva viene asociada a las nuevas variedades híbridas y modificadas genéticamente de las semillas resistentes al uso de herbicidas, que se difunden conjuntamente. 
Otro sistema tecnológico reciente, de incipiente difusión en el país, es la agricultura de precisión o satelital. Este proceso comienza en la etapa de cosecha con la construcción de un mapa en el cual se identifican regiones de productividad similar. Luego, se realizan muestras de los suelos menos productivos para determinar si los menores rendimientos responden a problemas de nutrición del suelo o de hierbas, enfermedades o plagas. De esta forma puede adaptarse la dosis de fertilizantes y agroquímicos a los requerimientos específicos de cada parte de la explotación, logrando aumentos de productividad y una mayor eficiencia en el uso de insumos, con una menor agresión al medio ambiente. Cabe destacar que su implementación requiere de inversiones importantes (acceso a información satelital, informatización de las actividades de siembra y cosecha, compra de equipos especializados).

\subsection{Contexto específico: el cultivo de soja}

Durante la década del '80, las regulaciones impuestas en el mercado agropecuario argentino, principalmente a partir de la operatoria de la Junta Nacional de Granos, junto al escaso nivel de apertura económica que impedía la capitalización del sector agropecuario, se constituyeron en los principales obstáculos de un mayor crecimiento de la producción de soja. No obstante ello, a lo largo de la década perdida, se produjo un incremento de poco más del $70 \%$ en los niveles de producción de esta oleaginosa.

La desregulación económica junto a una mayor apertura y a la eliminación de la Junta Nacional de Granos condujeron a un importantísimo crecimiento de la producción de soja, tanto en la década del '90 como en los primeros años del nuevo siglo. Así, en el período 1989-2003, el incremento de los niveles de soja producidos fue de más de $400 \%$.

\section{GRAFICO $\mathrm{N}^{\circ} 2$ \\ ÁREA SEMBRADA Y PRODUCCIÓN DE SOJA}

(1980-2003)

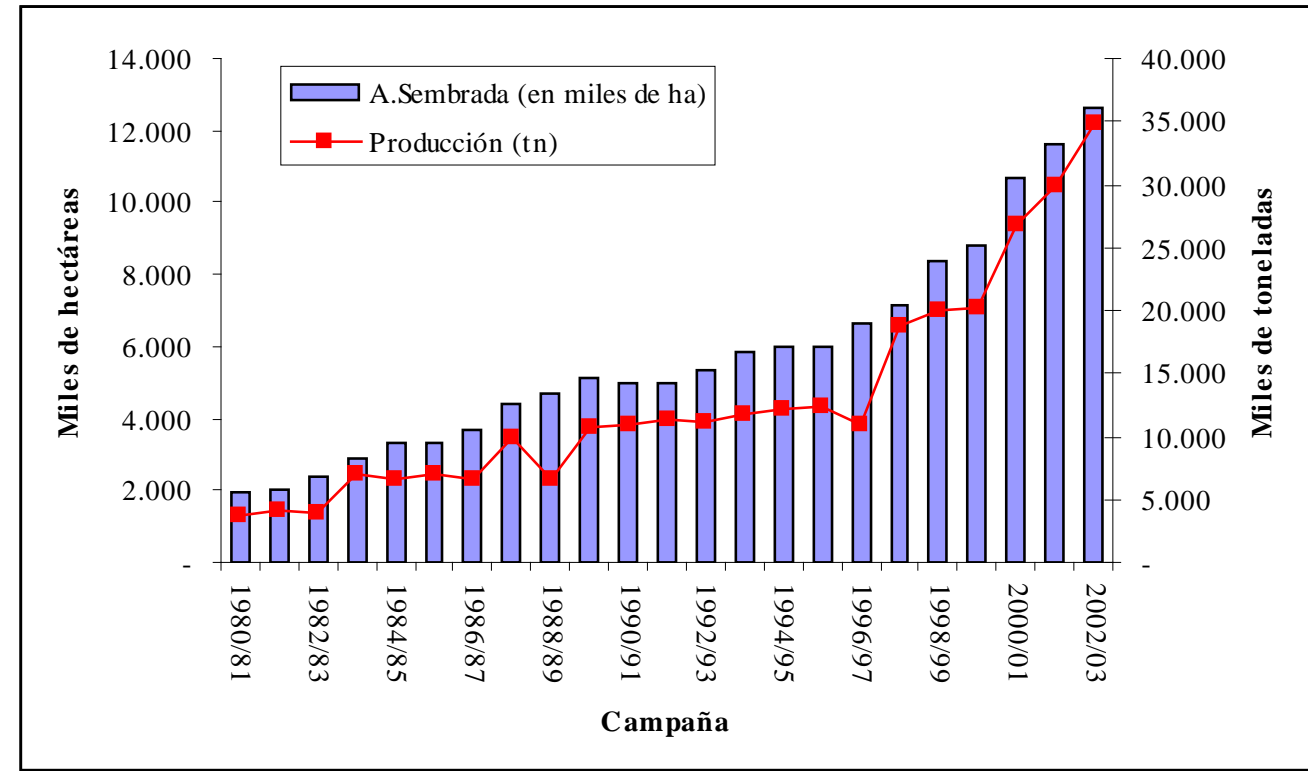

Fuente: elaboración propia en base a Secretaría de Agricultura Ganadería, Pesca y Alimentación (SAGPyA). 
Un primer salto se produjo con la eliminación de los derechos de exportación y la eliminación de la Junta Nacional de Granos a comienzos de la década del '90. El segundo salto en la producción (campaña 1997/98), estuvo explicado por la incorporación de semillas de soja transgénicas y la difusión del proceso de siembra directa. Estas nuevas tecnologías no sólo provocaron un aumento muy importante en los rindes, sino también en las hectáreas sembradas con granos oleaginosos (desplazando otros usos del suelo, tales como la cría de ganado).

Al momento de la realización de este trabajo, Argentina se constituía en el tercer productor de soja a nivel mundial, aportando el 18\% de la producción mundial de este commodity y es precedido solamente por EEUU y Brasil.

\section{GRAFICO N ${ }^{\circ} 3$ \\ PRINCIPALES PRODUCTORES DE SOJA}

(Año 2003)

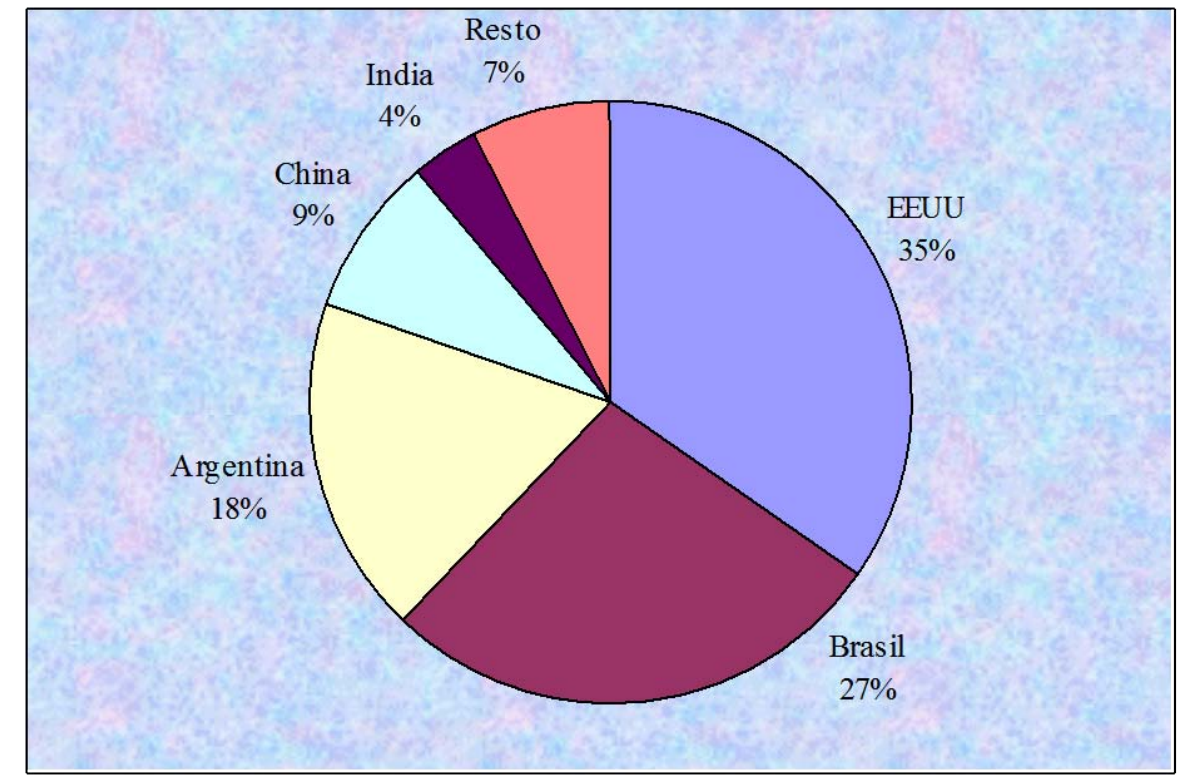

Fuente: elaboración propia en base a Food and Agriculture Organization (FAO).

La producción de soja en Argentina se encuentra relativamente atomizada; ya que se cultiva mayoritariamente en explotaciones de escala mediana, aunque en los últimos años el tamaño de las mismas ha ido en aumento (Gutman, 2000). ${ }^{4}$

Existe una marcada concentración regional en la producción de soja en Argentina, destacándose por sobre el resto las provincias de Santa Fe, Córdoba y Buenos Aires, que representan el 78\% de la producción nacional. ${ }^{5}$

La mayor parte de la producción de soja de Argentina se destina al mercado doméstico (cerca de un 80\%), específicamente a los molinos harineros y a las aceiteras. El resto se exporta principalmente a los países asiáticos (destacándose China, Tailandia y Malasia) y a la Unión Europea (especialmente a España, Holanda e Italia).

\footnotetext{
${ }^{4}$ Gutman G. (2000).

${ }^{5}$ En la campaña 2003, según datos de la SAGPyA. Santa Fe participa con poco más de un $29 \%$ de la producción nacional de soja; mientras que Córdoba y Buenos Aires aportan el 28\% y el 21\%, respectivamente.
} 


\section{GRAFICO $\mathrm{N}^{\circ} 4$ \\ DESTINOS DE LAS EXPORTACIONES DE SOJA ARGENTINAS}

(Año 2002)

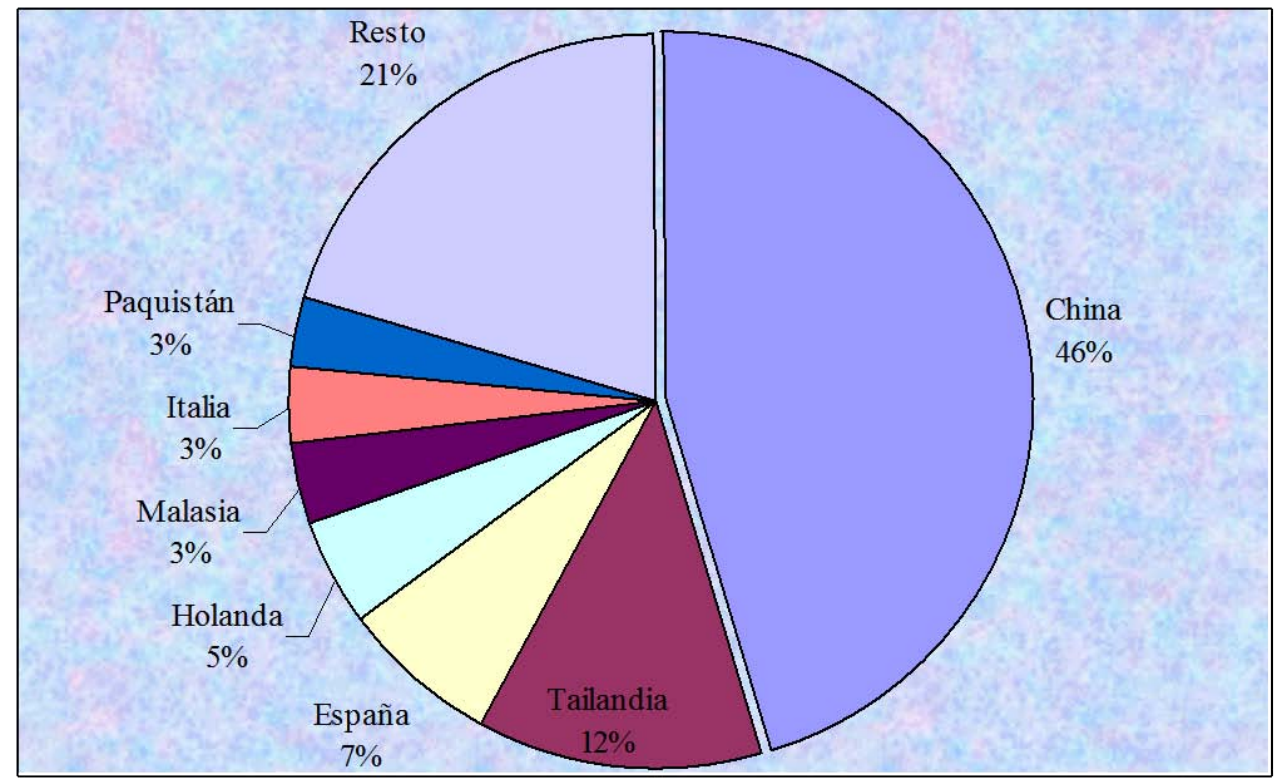

Fuente: Elaboración propia en base a Secretaría de Agricultura Ganadería, Pesca y Alimentación (SAGPyA).

A igual que nuestro país, la mayoría de los países del mundo destinan la mayor parte de su producción de soja al mercado doméstico. Es por ello, que a pesar de exportar una fracción muy pequeña de su producción de soja, Argentina se constituye en el tercer exportador a nivel mundial de esta oleaginosa; al igual que en la producción los países que la superan son EEUU y Brasil.

\section{GRAFICO $N^{\circ} 5$ \\ PRINCIPALES EXPORTADORES DE SOJA A NIVEL MUNDIAL}

(Año 2002)

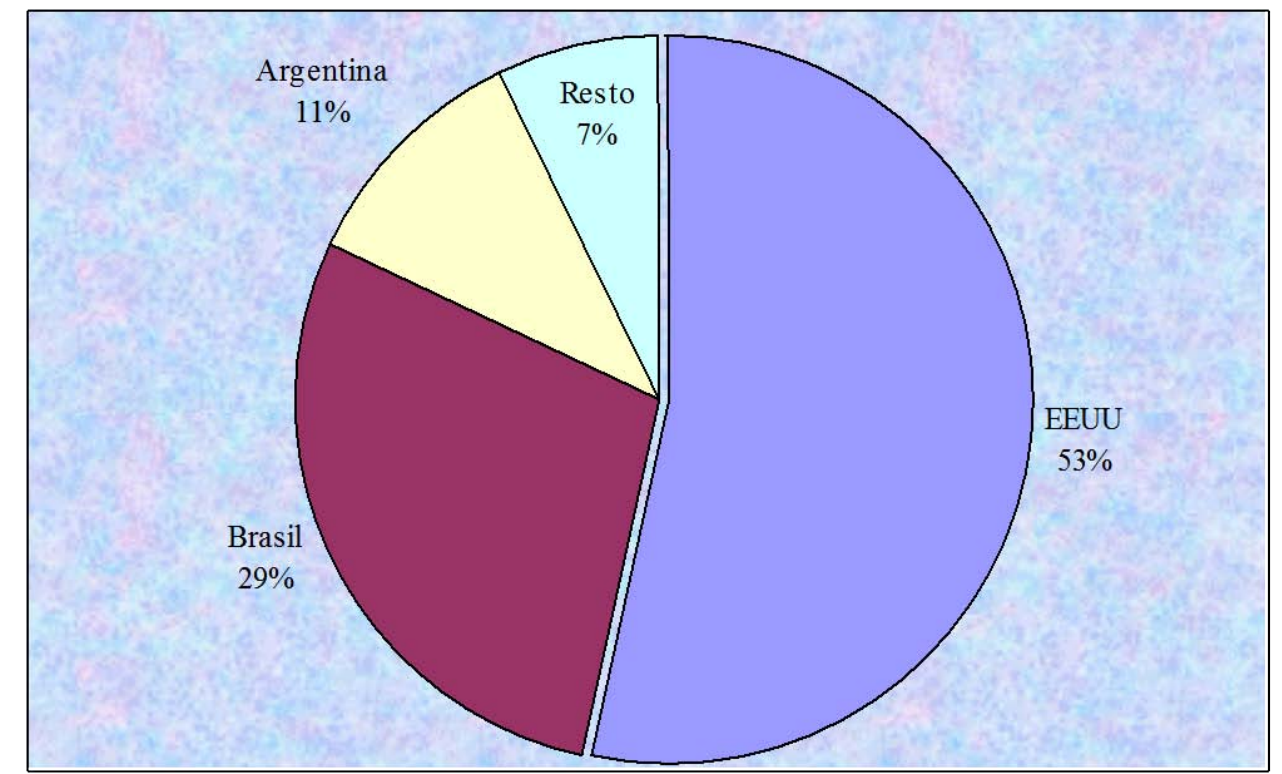

Fuente: elaboración propia en base a Secretaría de Agricultura Ganadería, Pesca y Alimentación (SAGPyA). 
Las molineras y aceiteras producen harinas (también denominada pellets) y aceites de soja, que se dirigen en su mayor parte al mercado externo ya que en nuestro país el consumo de aceite y harina de soja es muy bajo.

Según un trabajo publicado por el Ministerio de Economía de la provincia de Buenos Aires ${ }^{6}$, el principal demandante externo de los productos industrializados localmente derivados de la soja, es la Unión Europea, seguido por Asia y Africa. Los países americanos tienen una baja participación en la demanda externa, debido fundamentalmente a tres razones: (a) hay países americanos que son productores de aceites y harinas, como el caso de Brasil, (b) otros tienen una demanda interna muy reducida o (c) son abastecidos por otros productores, tales como Brasil y los EEUU.

El mismo trabajo remarca que Europa demanda básicamente harinas proteicas. Este hecho ocurre debido a que la UE es un importante productor de aceites; los principales importadores de harinas son Italia, España y Holanda. Asia es el comprador más importante de los aceites crudos producidos en el país, destacándose India, Irán y Bangladesh, que en conjunto adquieren el $41 \%$ de las exportaciones argentinas de este producto. Por último, el principal país importador de aceites refinados a granel producidos localmente, es China con más del 55\% de la demanda externa de estos productos, mientras que el $52 \%$ del aceite embotellado con marca se exporta hacia América, aunque Rusia es el país que individualmente importa mayor cantidad, con el $34 \%$ del total.

\section{MICROAMBIENTE EN EL QUE SE DESEMPEÑARÁ LA FIRMA}

\subsection{Competencia en el negocio de insumos agropecuarios ${ }^{7}$}

El mercado de insumos agropecuario se encuentra muy concentrado existiendo un número reducido de firmas que absorben la mayor parte del mercado. El nivel de rivalidad entre las firmas líderes es muy importante.

Firmas de capitales extranjeros como Cargill, Glencore, Dekalb están teniendo cada vez mayor participación en el mercado argentino de agroinsumos adquiriendo compañías locales. En general, las empresas semilleras disponen de una estructura de ventas muy importante con delegaciones en las principales ciudades localizadas en áreas productivas e incorporan otros insumos agropecuarios como fertilizantes y herbicidas, ya sea con marcas propias o de terceros.

Las elevadas inversiones necesarias para la producción de este tipo de bienes, principalmente en el área de investigación y desarrollo, se constituyen en una de las principales barreras de entrada a este mercado. A su vez los elevados costos hundidos que tienen estas firmas al comenzar su negocio se transforman en barreras de salida.

\subsection{Análisis de la competencia en el mercado de inoculantes}

Dada la escasa disponibilidad de datos acerca del mercado de inoculantes, se consideró relevante efectuar una encuesta entre agricultores con el fin de comprender el perfil de la competencia y de los consumidores. La encuesta que se presenta en el

\footnotetext{
${ }^{6}$ Ver Cuaderno de Economía No 64 (2002).

${ }^{7}$ Ver Gutman (2000).
} 
Anexo a este trabajo, se realizó durante los días 13, 14, 15 y 16 de marzo de 2003 entre productores que asistieron a la megaexposición agropecuaria FeriaAgro en la ciudad de Junín. La muestra incluyó a 54 agricultores localizados en el mercado geográfico objetivo y 80 productores de otras regiones del país.

\subsubsection{Competencia actual}

Para determinar la participación de cada empresa en el mercado de inoculantes en los municipios próximos a Junín, se tomaron las respuestas de los encuestados y se ponderó por la cantidad de hectáreas que sembró cada uno de ellos.

El Gráfico que se presenta a continuación muestra la participación de mercado de cada una de las empresas productoras de inoculantes.

\section{GRAFICO $\mathrm{N}^{\circ} 6$ \\ PARTICIPACION DE MERCADO DE INOCULANTES (MERCADO OBJETIVO)}

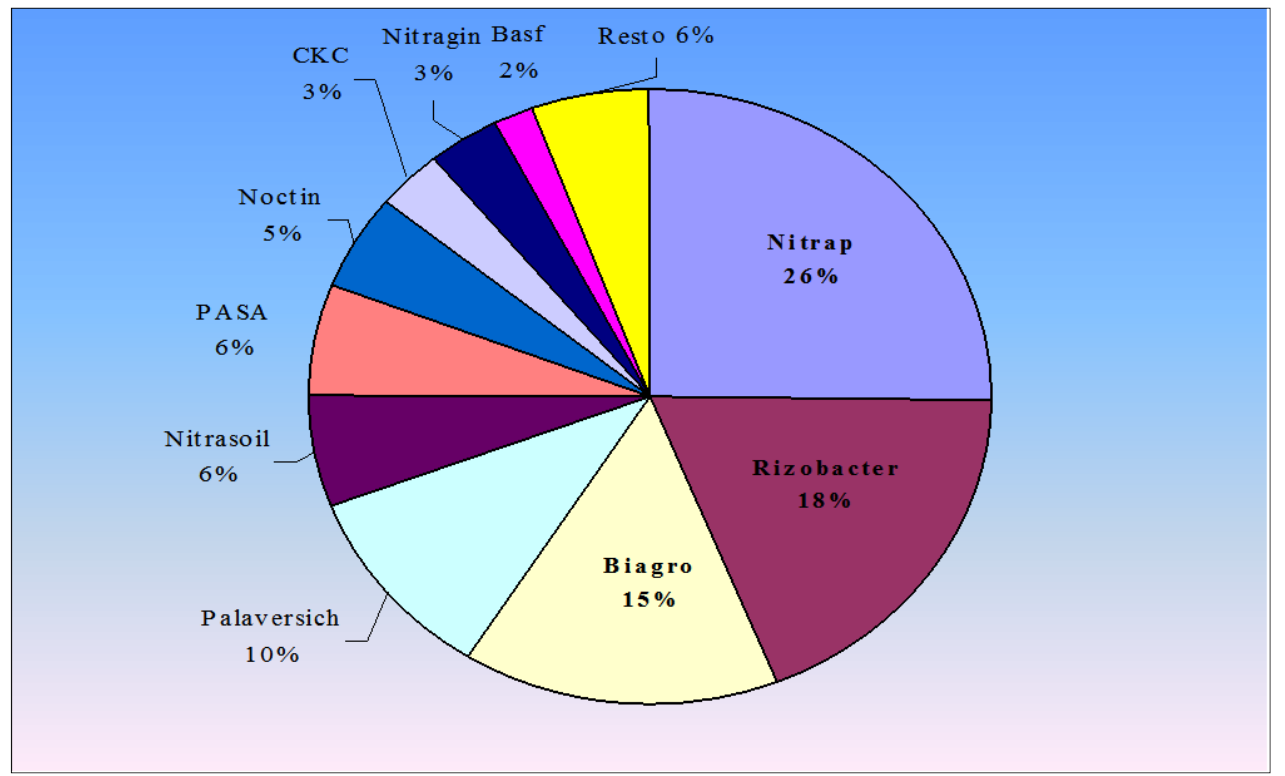

Fuente: elaboración propia en base a encuesta a productores agrícolas.

Entre los resultados salientes se encuentra que la firma Nitrap, una pequeña empresa localizada en la región (municipio de Ameghino) absorbe el 26\% de mercado, mientras que Rizobacter (ubicada en la ciudad de Pergamino) posee un 18\% del mercado objetivo y Biagro un 15\%. Las tres primeras firmas concentran el 59\% del mercado, en tanto que un número importante de firmas se reparten el resto del mercado.

La concentración del mercado también puede medirse por el tradicional Indice de Hirschman Herfindahl Index (HHI), que se calcula a partir de elevar al cuadrado las participaciones de cada una de las empresas y sumar dichos resultados.

El resultado obtenido fue 1443, según la US Trade Commission de EEUU este valor denota un mercado en donde la concentración es moderada. Dicho organismo entiende que si el HHI es inferior a 1000 la concentración de mercado es baja, si se ubica entre 1000 y 1800 es moderada y si supera los 1800 es elevada. 


\subsubsection{Competencia potencial}

Más allá de este análisis, a partir de la misma encuesta se trató de identificar competidores potenciales, estudiando la participación de mercado de cada una de las firmas en el resto del país.

Efectuando el mismo procedimiento que en el caso anterior, se encontró que el mercado de inoculantes del resto del país se encuentra distribuido de la siguiente manera.

\section{GRAFICO $\mathrm{N}^{\circ} 7$ \\ PARTICIPACION DE MERCADO DE INOCULANTES (RESTO DEL PAIS)}

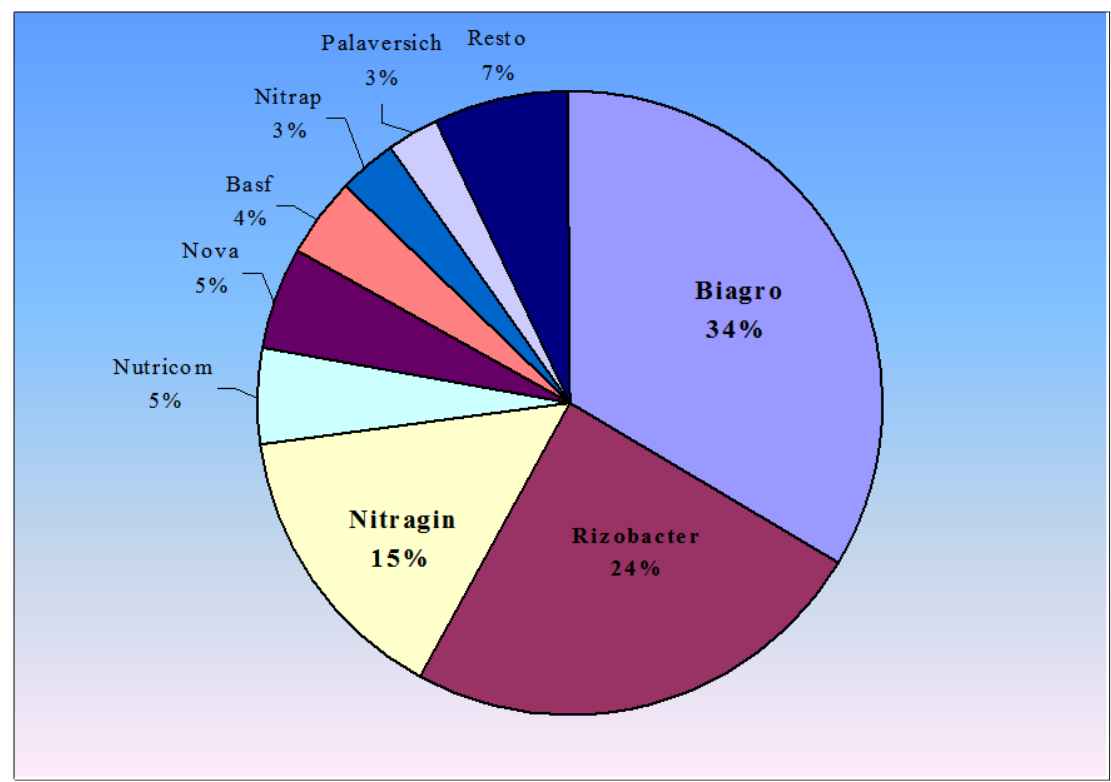

Fuente: elaboración propia en base a encuesta a productores agrícolas.

En este caso la firma Biagro absorbe el 34\% del mercado, seguida por Rizobacter (24\%) y Nitragin (15\%). Así, las tres primeras firmas concentran el 73\% del mercado, quedando una escasa porción para el resto de los competidores.

Si bien no existe información oficial respecto la participación del mercado de cada firma, en los últimos años se ha observado un importante crecimiento de la firma Rizobacter y se estima que esta empresa estaría concentrando más del 30\% de las ventas de inoculantes en el país, desplazando a Biagro del primer lugar.

A su vez, el HHI presenta un número sustancialmente mayor al observado en el mercado objetivo, arrojando un valor de 2032, es decir el mercado se encuentra altamente concentrado según los estándares internacionales.

Una de las conclusiones que pudieron obtenerse a partir de los resultados que arrojó la encuesta respecto al mercado del resto del país es que existen grandes firmas que al momento del sondeo ostentaban una participación de mercado limitada en la región objetivo (específicamente Biagro y Nitragin) pero que podrían constituirse en potenciales competidores en el futuro. 


\subsubsection{Análisis de los competidores actuales y potenciales (Players)}

\section{Nitrap $S . A^{8}$}

Esta firma está localizada en el municipio de Ameghino, en el noroeste de la provincia de Buenos Aires. Es una empresa familiar que comenzó a operar a comienzos de la década del '90.

Se dedica a la elaboración de inoculantes líquidos y la mayor parte de su producción se envasa en bidones de 5 litros. En sus envases tiene toda la información exigida por SENASA, como fecha de elaboración, vencimiento, contenido de bacterias, etc.

Esta firma apunta a un segmento de consumidores que prefieren precios bajos, cobrando por sus productos uno de los menores precios del mercado.

Para promocionar sus productos, visitan semilleras ubicadas en ciudades cercanas a Ameghino y tienen una relación muy estrecha con los productores agropecuarios de la zona. Mediante este mecanismo pueden vender toda su producción y no consideran necesaria la publicidad de sus productos en ningún medio de importancia ni disponen de página web propia.

\section{Laboratorios Biagro S. $A^{9}$}

La empresa está ubicada en el Parque Industrial General Las Heras en la ciudad homónima y opera desde el año 1984. Su principal actividad es la producción de inoculantes para soja pero además elabora protectores y mejoradores de semilla, y enzimas.

La firma está constituida por distintos departamentos: Técnico, Investigación y Desarrollo, Administración, Ventas y atención al cliente, y Atención a proveedores.

El inoculante para soja es envasado en un recipiente de plástico, conteniendo toda la información referida a las características del producto (sus componentes, fecha de vencimiento) y se especifica el modo de uso.

\footnotetext{
${ }^{8}$ El análisis de esta empresa, se efectuó a partir de distintas reuniones mantenidas con los gerentes de la firma Agroinvest.

${ }^{9}$ Información obtenida en http://www.biagrosa.com.
} 


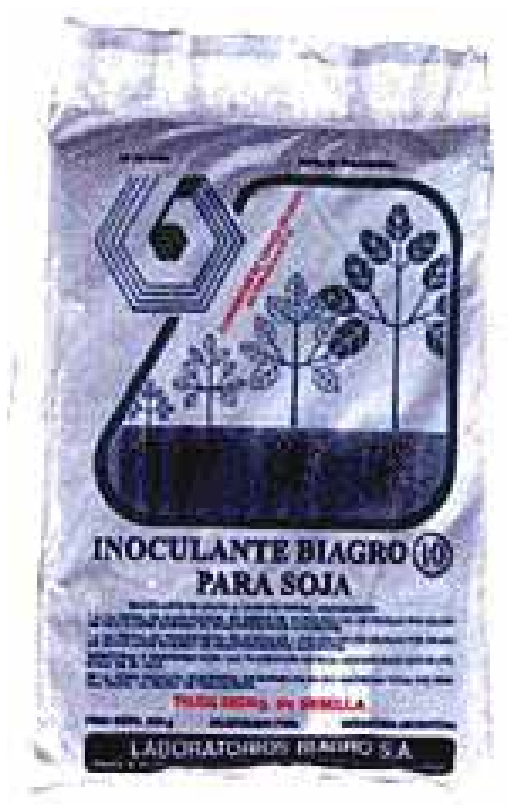

Esta empresa se ubica en un segmento de elevada calidad a partir de importantes inversiones en tecnología y marketing. Su reputación en el mercado permite a esta firma vender sus productos a un precio superior al promedio del mercado. En general, al igual que lo que ocurre con la mayoría de las empresas del sector, el único modo de financiamiento que provee a sus clientes es mediante el pago a cosecha.

La distribución se concentra en diversos proveedores independientes localizados en distintas áreas geográficas y una pequeña fracción de la venta se realiza a través del departamento de ventas y atención al cliente.

Para promocionar su producto Biagro dispone de una página web en donde informa sobre información general de la empresa, los convenios que mantienen con distintas instituciones (universidades, INTA, etc.), la infraestructura con la que cuenta, los productos que comercializa además de exponer un número importante de ensayos realizados con sus productos. Además, expone su publicidad en distintos medios del sector agropecuario en general utilizando resultados de sus ensayos como principal argumento publicitario.

\section{Rizobacter Argentina S.A.}

Rizobacter Argentina S.A. es una empresa argentina, nacida en la ciudad de Pergamino en el año 1977. La firma tiene una importante reputación en el mercado interno y en los últimos años ha aumentado significativamente su inserción externa, vendiendo a países limítrofes como Brasil, Bolivia, Uruguay y Paraguay y ya ha incursionado en algunas ventas hacia el continente asiático, principalmente a China. Opera en el mercado agropecuario en sus tres principales líneas de productos: Inoculantes para semillas de leguminosas, curasemillas líquidos de aplicación directa sobre las semillas y coadyuvantes de uso agrícola.

La visión de la empresa, presentada en su página web, ${ }^{10}$ aspira a estar entre las empresas líderes a nivel mundial en investigación, desarrollo, producción y comercialización de productos microbiológicos, con aplicación en múltiples segmentos

\footnotetext{
${ }^{10}$ En http://www.rizobacter.com.ar/esp/laempresa/nuestravision.html.
} 
del mercado de agroinsumos, sirviéndose para ello de las más avanzadas tecnologías enfocando su accionar hacia los nichos más novedosos y menos competitivos. También pretende la satisfacción total del cliente a partir del trabajo en equipo. Por su parte la misión prevé concentrar esfuerzos en productos microbiológicos y servicios que potencien el desarrollo a sus mercados e incrementen su rentabilidad, teniendo como premisa la preservación del medio ambiente, accediendo a tecnologías de punta por medios propios o alianzas estratégicas. Contando con certificación bajo normas internacionales de calidad ISO 9002 en sus procesos claves. Apuntando a captar y retener clientes de vanguardia que aprecien el valor agregado que da la investigación, la alta tecnología y el servicio de pos venta siendo flexibles y ágiles en la adaptación a los cambios de sus mercados actuales y potenciales y esforzándose para responder en tiempo real a las necesidades de los clientes vislumbrando las nuevas necesidades, los cambios y tendencias, con el tiempo suficiente para llegar primero.

Rizobacter produce distintos tipos de inoculantes que presenta en diversos envases. Se destaca en la comercialización de Rizo-Liq que se vende en cajas de 25 sachets de $400 \mathrm{~cm}$. cúbicos cada uno. Otro tipo de inoculante vendido por esta empresa es el Rizoplus Super es un inoculante formulado con un soporte de turba estéril (sólido) y es presentado en envases de 150 gramos que alcanza para inocular 50 kilogramos de semillas. Por último, Risoja es también un inoculante sólido que se presenta en un envase de 200 gramos y alcanza para inocular 50 kilogramos de semilla. ${ }^{11} \mathrm{~A}$ continuación se presentan las imágenes de los distintos tipos de inoculantes comercializados por Rizobacter.

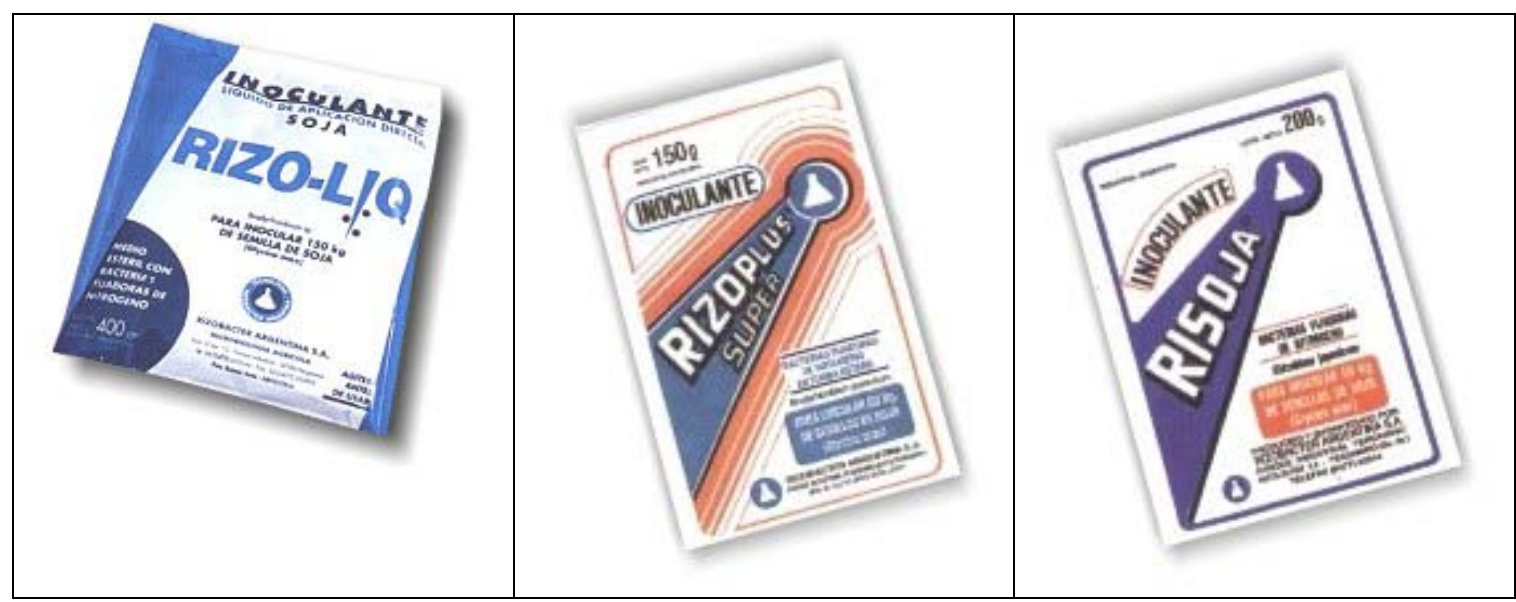

De acuerdo a las reuniones mantenidas con los gerentes de Agroinvest, se observa que Rizobacter, al igual que Biagro, apunta a un segmento del mercado que prefiere adquirir inoculantes con probada calidad a expensas de pagar un precio mayor por el producto. Esta firma, realiza descuentos por pago contado y buena parte de sus ventas de inoculantes se efectúan mediante financiación con pago a cosecha.

Al igual que en el caso anterior, los envases contienen toda la información referida a las características del producto (sus componentes, fecha de vencimiento) y se especifica el modo de uso. También se indica que no posee elementos contaminantes.

\footnotetext{
${ }^{11}$ La mayoría de los inoculantes se presentan en dosis que sirvan para mezclar en $50 \mathrm{~kg}$. de semillas de soja que es la forma usual en la que se comercializa la semilla de esta oleaginosa.
} 
En general esta información se repite en todos los envases de inoculantes de diversas marcas ya que existen requisitos impuestos por la entidad que regula la comercialización de este insumo agropecuario, el SENASA.

La empresa cuenta con una amplia red de distribuidores que abarca toda la zona agrícola argentina, desde el sur de la provincia de Buenos Aires hasta el norte del país. Sumando los distribuidores localizados en las tres principales provincias argentinas, Buenos Aires, Santa Fe y Córdoba, la firma cuenta con 336 distribuidores.

Para promocionar su producto Rizobacter cuenta con una página web en la cual se informa acerca de los aspectos generales de la firma, los productos que comercializa, los servicios que ofrece, sus canales de distribución, diversos informes que muestran las bondades de los productos que comercializa y un link para contactarse con representantes de la empresa. Además, expone su publicidad en distintos medios del sector agropecuario, principalmente páginas web como www.buscagro.com, www.viarural.com.ar y en revistas especializadas.

\section{Nitragin Argentina $S . A^{12}$}

Desde 1975 como Nitragin S.A., y luego como Nitragin Argentina S.A., no solamente participa activamente en el desarrollo, producción y comercialización de inoculantes, sino que, más recientemente, la empresa se ha convertido en líder en tratamiento de semillas de leguminosas. Es miembro del grupo Merck (Corporativa del ramo Química y Farmacéutica) posee toda la información tecnológica y la estructura necesaria para desarrollar sus productos.

Nitragin produce inoculantes para soja líquidos presentados en dos tipos de envases. Nitragin Cell Tech 150, es un inoculante líquido presentado en 60 sachets de $150 \mathrm{ml}$. por caja. Cada sachet es mezclado con $50 \mathrm{~kg}$. de semillas. Nitragin Cell Tech SD se presenta en una bolsa conteniendo 7,5 litros de inoculantes y un kit dosificador compuesto por una válvula dosificadora, una manguera y una jarra. A su vez existe una presentación adicional que combina ambos tipos de inoculantes con un fungicida.

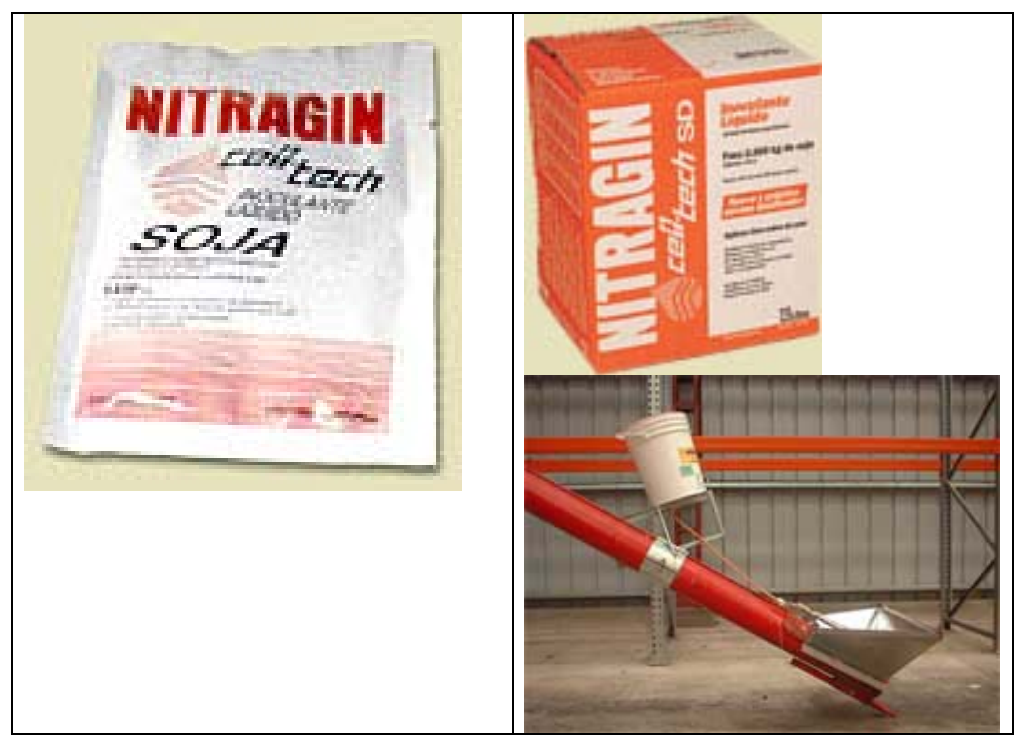

\footnotetext{
${ }^{12}$ Información recabada de la página http://www.nitragin.com.ar.
} 
Además de las distintas especificaciones técnicas del producto, en el caso de Nitragin Cell Tech SD existe un manual que explica como dosificar la aplicación del inoculante.

Nitragin, vende sus productos mayormente mediante pago a contado, efectuando importantes descuentos mediante este mecanismo. A su vez, financia a los productores mediante el método más utilizado por las firmas del sector: pago a cosecha. El precio contado de los productos vendidos por esta firma son levemente inferiores a los cobrados por Biagro y Rizobacter.

Para distribuir sus productos Nitragin cuenta en la provincia de Buenos Aires con 5 delegaciones regionales (Tandil, 25 de Mayo, Chacabuco, Pehuajó y Junín) coordinadas por una Gerencia Regional localizada en Junín. En las provincias de Santa Fe y Córdoba cuentan con una estructura comercial similar.

Nitragin es una de las firmas que más hincapié hace en la promoción de sus productos. Además de una página web muy bien presentada, expone pautas publicitarias en las principales revistas especializadas del sector agropecuario.

\section{Barenbrug-Palaversich S.A $A^{13}$}

En noviembre de 1999, Palaversich se ha transformado en una compañía 100\% del Grupo Barenbrug, fundado en 1904, y permanece siendo una empresa familiar, cuya casa central se encuentra en Holanda. Hoy también cuenta con varias sucursales en distintos países del mundo, estando presente en los cinco continentes. En Argentina, esta empresa posee su planta de producción en la ciudad de Pergamino, en la provincia de Buenos Aires.

Esta firma produce inoculantes para soja líquido y recientemente ha desarrollado un nuevo inoculante que combina el tradicional líquido con una mínima proporción de turba para mejorar la absorción del producto al aplicarlo a la semilla y prolonga la acción de los rizobios. De esta manera se buscó mejorar la facilidad de la aplicación de este insumo.

Al poseer varias gamas de productos esta firma abastece a productores que demandan precios más bajos y a aquellos que están dispuestos a pagar un precio más alto debido a que valoran significativamente la facilidad en el uso de la aplicación de este insumo agropecuario.

En la distribución de sus productos, Palaversich-Barenbrug, divide regionalmente sus áreas de operaciones contando con 6 representantes en las provincias de Buenos Aires (3), Córdoba (1), La Pampa (1) y Santa Fe (1). A su vez dispone de 8 depósitos localizados en las ciudades de 25 de Mayo, Lobos, Chascomús y Tandil (Buenos Aires), General Pico (La Pampa), Nogoyá (Entre Ríos), Río Cuarto y San Francisco (Córdoba).

Palaversich-Barenbrug basa su estrategia de promoción a partir de la exposición de ensayos en diversos medios publicitarios. Para ello cuenta con 3 espacios de pruebas en las ciudades de Balcarce y Pergamino (Buenos Aires) y Rafaela (Santa Fe). También

\footnotetext{
${ }^{13}$ Información recabada de la página http://www.barenbrug.com.ar
} 
cuenta con una página web, pero la misma no expone información relevante, más allá de datos sobre la compañía, los productos que comercializa (sin presentar fotos de los mismos), un link con contactos, un espacio para atención a clientes y un sitio en donde se muestra una breve descripción de algunos trabajos de investigación.

\subsection{Perfil de los consumidores de inoculantes}

\subsubsection{Características del consumidor típico}

A partir de los resultados de la encuesta elaborada es posible identificar las características principales de los potenciales consumidores en tres aspectos relevantes: la escala de operaciones, la manera en la que se informan acerca de los beneficios del producto y su fidelidad hacia una marca determinada.

De acuerdo a los resultados registrados en la encuesta se encuentra que la mayor parte de los productores de soja siembran menos de 700 hectáreas (82\% de los consultados). Como se aprecia en el siguiente gráfico, dentro de dicho grupo sobresalen aquellos que siembran entre 100 y 300 hectáreas.

\section{GRAFICO $\mathbf{N}^{\circ} 8$ \\ ESCALA DE OPERACIONES DE LOS PRODUCTORES DE SOJA}

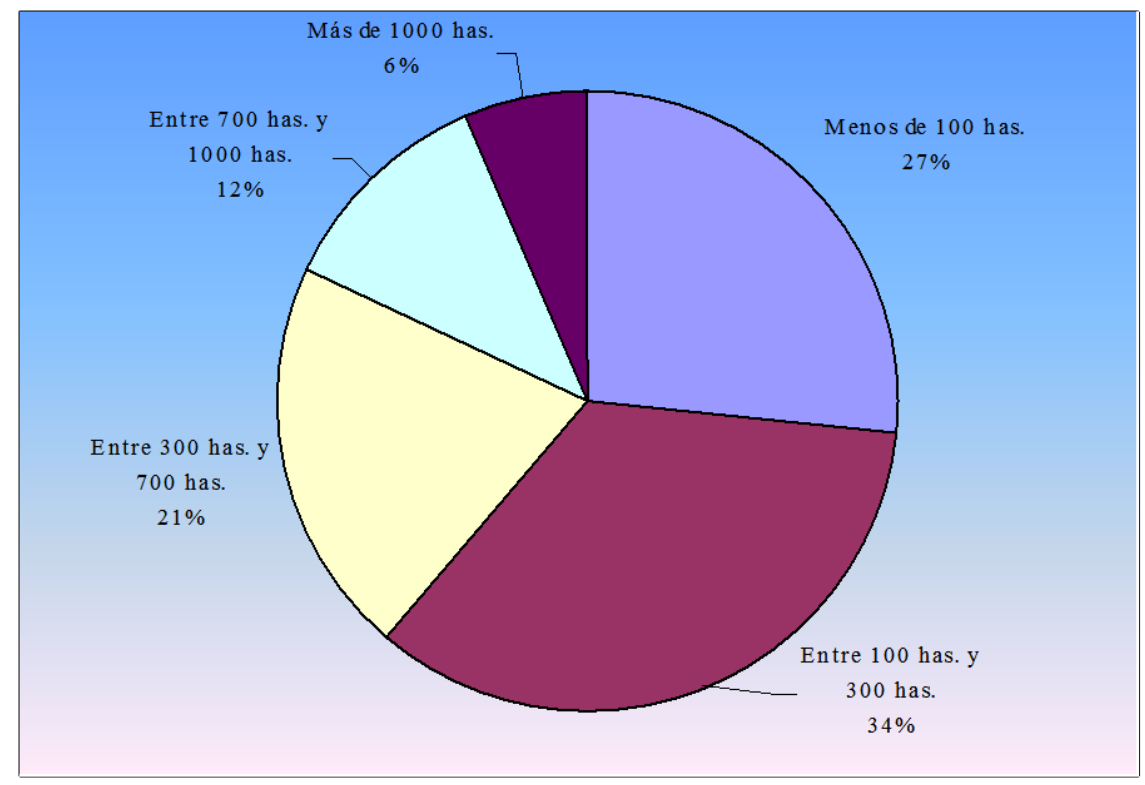

Fuente: elaboración propia en base a encuesta a productores agrícolas.

En la encuesta también se intentó captar la manera en que el consumidor se informa para adquirir este tipo de producto. Los resultados obtenidos en el mercado objetivo demuestran que buena parte de los productores conocieron el inoculante a partir de folletos de la empresa presentados por los distribuidores (28\%), la transmisión de experiencias a través de productores también se constituye en una buena fuente de información para los agricultores (14\%), mientras que el $13 \%$ de los consultados conocieron el inoculante que utilizan por consejos de Ing. Agrónomos. 


\section{GRAFICO No 9 \\ PROMOCION Y PUBLICIDAD (MERCADO OBJETIVO)}

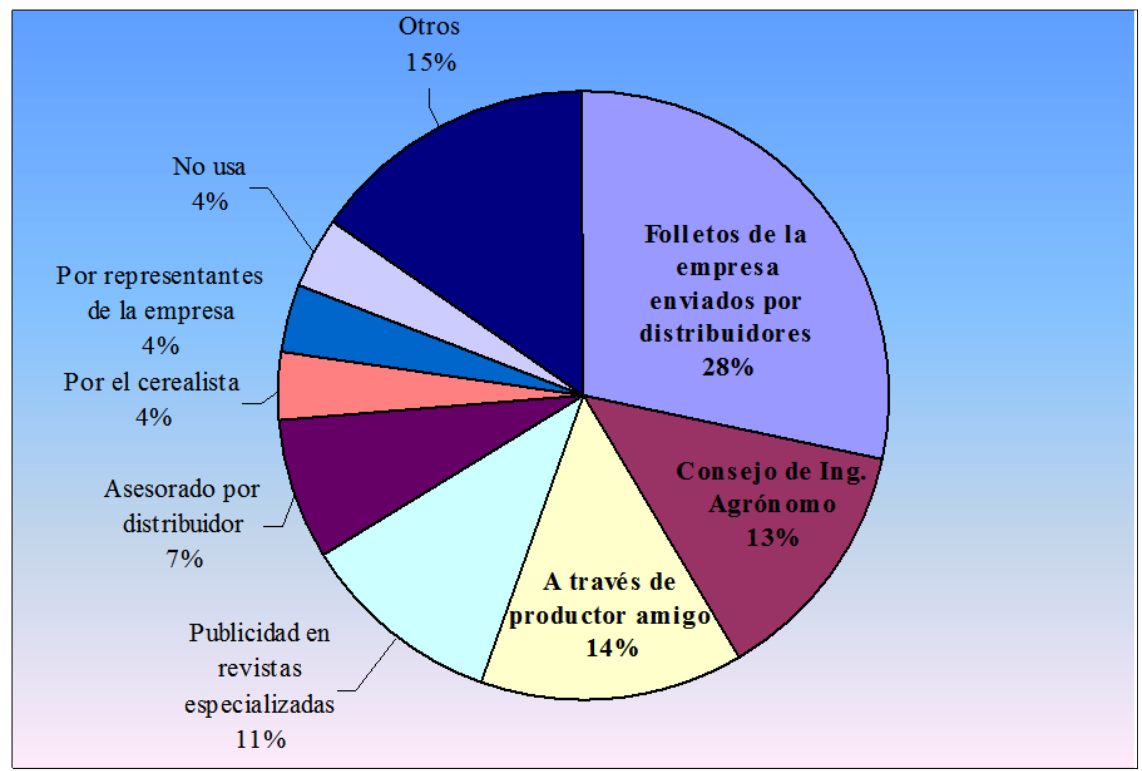

Fuente: elaboración propia en base a encuesta a productores agrícolas.

De este modo, debe tenerse presente que los consejos de los distribuidores se constituyen en uno de los principales determinantes de la elección de un inoculante. En general, los distribuidores se dedican a la venta de todo tipo de insumos agropecuarios y se localizan en la mayoría de las ciudades en donde se cuenta con tierras aptas para la producción de soja. Es decir los distribuidores se encuentran muy atomizados.

Otra característica del mercado objetivo es que los usuarios de inoculantes parecen no tener una marcada fidelidad hacia la marca del producto utilizada. En este sentido, se observa que el $67 \%$ de los consultados hace menos de 4 años que utiliza el mismo inoculante y el 89\% está dispuesto a cambiar por un nuevo inoculante. El hecho que los distribuidores van modificando los inoculantes ofrecidos a sus clientes a partir de acuerdos alcanzados con distintas firmas productoras de este insumo, hace que la fidelidad de los consumidores finales no sea muy marcada.

\subsubsection{Beneficios buscados por los consumidores}

De la encuesta se desprende que el precio es una de las características más valorada por los productores agropecuarios. De igual modo, se percibe que otros atributos son muy tenidos en cuenta por los potenciales clientes, principalmente aquellos relacionados con la calidad del producto y la facilidad en su uso.

En el mercado objetivo, se observa que el $29 \%$ de los consultados respondieron que el precio es el atributo excluyente que tienen en cuenta a la hora de adquirir su inoculante. La facilidad en el uso y la calidad le siguen con un 15\% mientras que un $14 \%$ le asigna la misma importancia al precio y a la calidad. 


\section{GRAFICO N 10 \\ ATRIBUTOS VALORADOS POR LOS USUARIOS (MERCADO OBJETIVO)}

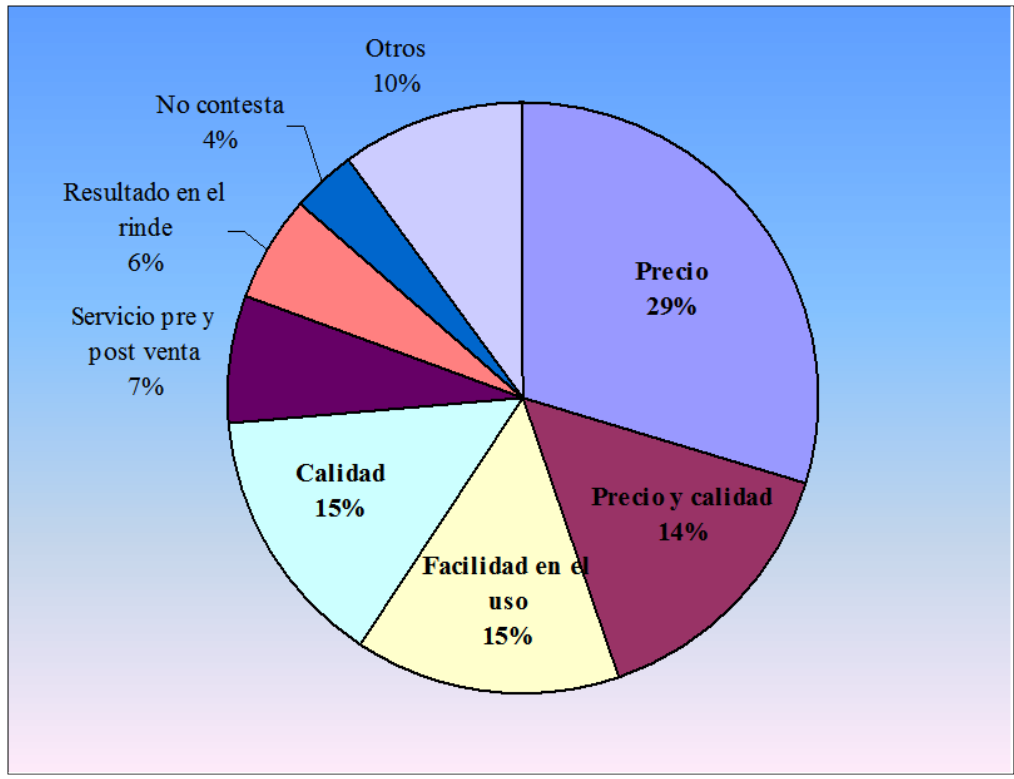

Fuente: elaboración propia en base a encuesta a productores agrícolas.

La elaboración de la encuesta también intentó captar las características del producto a comercializar. Teniendo en cuenta que existen diversos tipos de inoculantes, se intentó identificar cuál es el preferido por los agricultores. En este aspecto se indagó sobre tres cuestiones: las características físicas del producto (líquido, polvo, etc.), el envase y el tamaño de este último.

\section{GRAFICO $\mathbf{N}^{\circ} 11$}

CARACTERISTICAS FISICAS DEL INOCULANTE (MERCADO OBJETIVO)

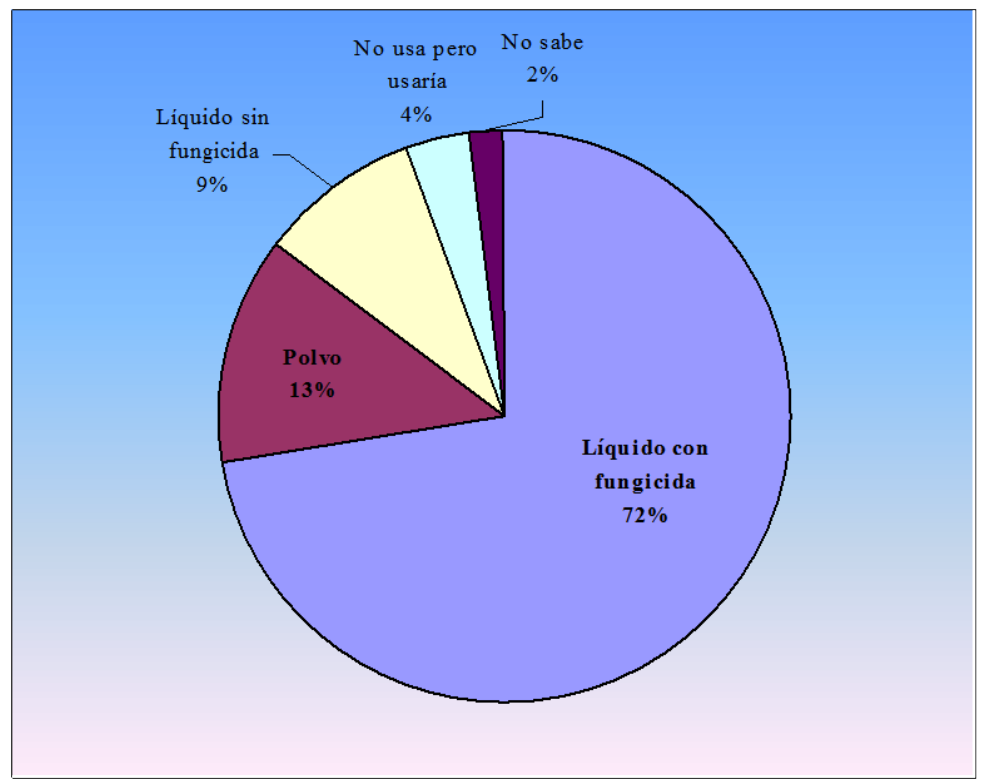

Fuente: elaboración propia en base a encuesta a productores agrícolas.

En lo que respecta a las características físicas se encontró que, tanto en el mercado objetivo como en el resto del país, predomina el uso de inoculantes líquidos con fungicida. 
En el mercado objetivo casi dos terceras partes de los entrevistados coincidieron en responder que utilizan inoculantes líquidos con fungicidas, sólo un 13\% dijo que usa inoculante en polvo. Si se suman las participaciones de inoculantes líquidos (con y sin fungicida) se encuentra que entre ambos absorben más del 80\% del mercado objetivo de inoculantes. Por su parte, se encontró que una pequeña fracción de los encuestados no utiliza inoculantes (4\%) y un porcentaje menor no sabe el tipo de inoculante que utiliza (2\%).

En lo referente al tipo de envase se encontró que en el mercado objetivo el $43 \%$ de los consultados respondió que adquiere inoculantes en sachets, mientras que el $23 \%$ lo recibe en bidones y el $17 \%$ en bolsas.

\section{TIPO DE ENVASE (MERCADO OBJETIVO)}

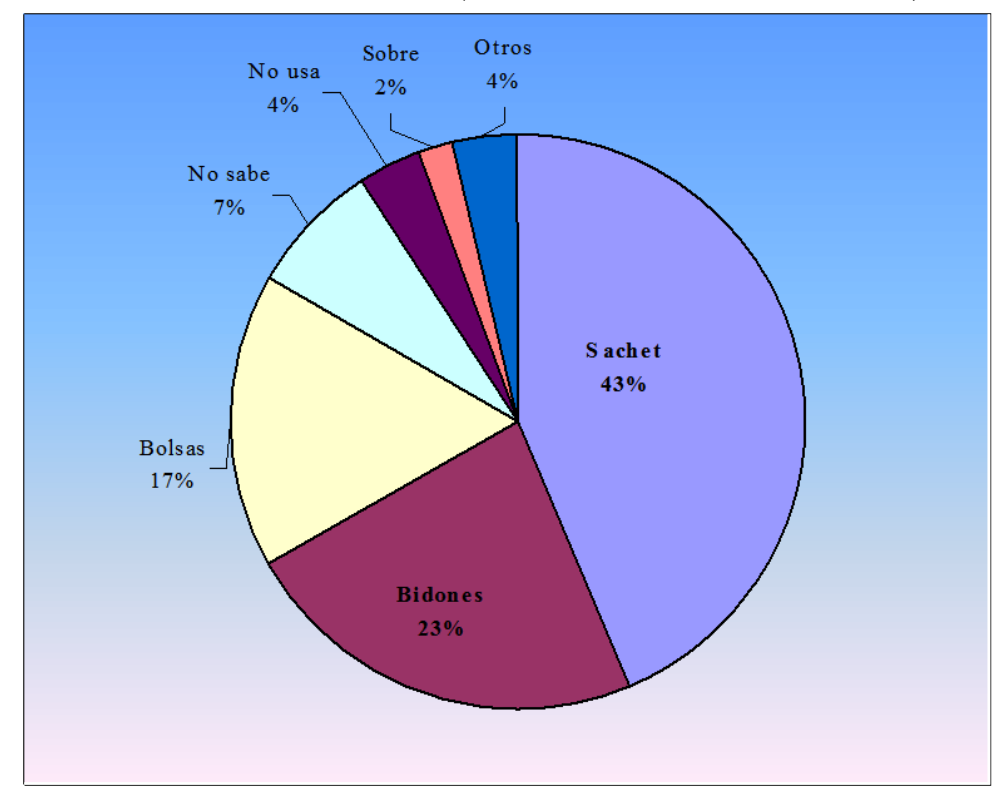

Fuente: elaboración propia en base a encuesta a productores agrícolas.

Respecto al tamaño del envase se observa una gran heterogeneidad y muchos de los consultados no saben qué cantidad de inoculante posee cada envase que adquiere. 


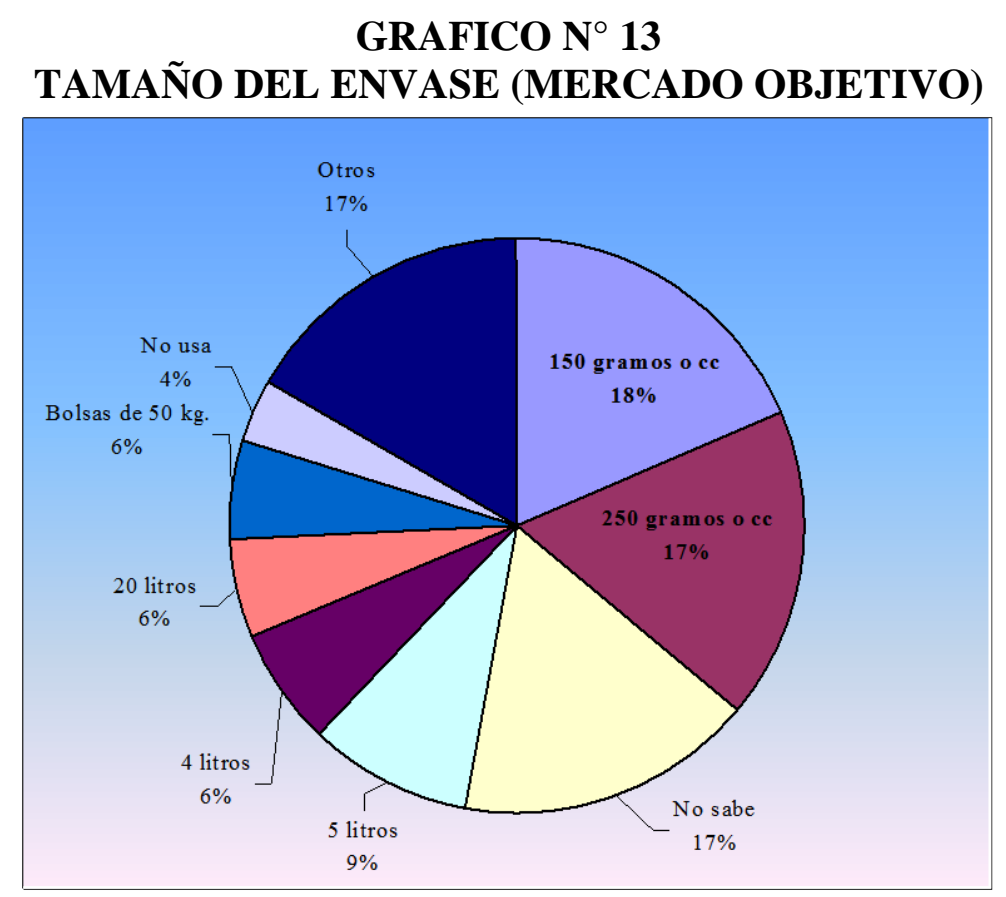

Fuente: elaboración propia en base a encuesta a productores agrícolas.

En el mercado objetivo, un 35\% de los consultados respondió que utiliza envases pequeños (150 o 250 gramos o cc.), mientras que existe un porcentaje muy elevado de agricultores que no conocen el tamaño del envase del inoculante: $17 \%$.

\section{ANÁLISIS FODA ${ }^{14}$}

El análisis FODA deviene de las cuatro primeras letras de Fortalezas, Oportunidades, Debilidades y Amenazas. Esta herramienta de marketing tan utilizada en la actualidad, fue ideada por Kenneth Andrews y Roland Christensen hace más de 20 años y se utiliza para comprender la situación actual de una empresa, organización, etc. y prevenir eventos futuros.

Utilizar esta técnica permite tomar una mejor posición ante una negociación, estudiar la forma en que una empresa orienta una venta y en muchas otras situaciones. Su objetivo central es ayudar al empresario a diagnosticar para, en función de ello, poder decidir.

Dentro de este análisis pueden identificarse dos tipos de variables: controladas y no controladas. Las primeras son internas de la empresa (Fortalezas y Debilidades) y por lo tanto se puede actuar sobre ellas con mayor facilidad. En cambio, las variables no controladas por la firma (Oportunidades y Amenazas) las presenta el contexto, el ambiente o la situación y la mayor acción que puede tomar un empresario o gerente con respecto a ellas es preverlas y actuar siguiendo los pasos que considere pertinentes en cada situación particular.

\subsection{Fortalezas}

\section{Localización estratégica}

\footnotetext{
${ }^{14}$ Esta introducción se basa en un artículo publicado en la página web de Estrategia Magazine.
} 
Reducción de costos mediante fabricación propia de varios insumos

$\checkmark$ Participación de un gran productor agropecuario en el negocio

$\checkmark$ Importante conocimiento del mercado a partir de una encuesta de campo dirigida a potenciales compradores

\subsection{Oportunidades}

El cultivo de soja crece año tras año en el país y en la región objetivo

$\checkmark$ La utilización de inoculantes ha crecido año tras año pero aún existe margen para un crecimiento mayor

$\checkmark$ Los bajos costos internos con un tipo de cambio favorable posibilitarían la inserción externa de la firma

\subsection{Debilidades}

$\checkmark$ Se trata de una firma nueva en un mercado donde existen muchas firmas con gran reputación

$\checkmark$ El hecho de ser una empresa nueva en el mercado conlleva a la falta de relaciones con distribuidores

$\checkmark$ Debido al mismo motivo que en el caso anterior, no existen relaciones con proveedores de diversos insumos necesarios para la producción de inoculantes

$\checkmark$ Los avances tecnológicos son cada vez mayores y se requieren cada vez mayores esfuerzos para adaptarse a los mismos

\subsection{Amenazas}

$\checkmark$ Las condiciones climáticas constituyen todos los años una amenaza para el sector agropecuario

$\checkmark$ La volatilidad macroeconómica (específicamente del tipo de cambio) podría reducir la competitividad del sector agropecuario, uno de los sectores más dinámicos en la economía argentina en la coyuntura actual

$\checkmark$ Existen grandes empresas que no poseen una elevada participación en el mercado objetivo pero que tienen una elevada participación en el mercado nacional, por lo cual existe el riesgo latente de un aumento de la competencia

\subsection{Cómo usar las fortalezas}

La localización estratégica de la firma (cercana al productor) permitirá reducir costos en la distribución y en la promoción del producto.

La reducción de costos en la fabricación de algunos insumos favorecerá una reducción en el precio del producto.

La participación en el negocio de un importante productor agropecuario posibilitará tener una importante venta asegurada, además de aprovechar las relaciones laborales (networking) de este socio.

A partir del conocimiento de mercado, se podrán desarrollar las estrategias de marketing adecuadas. 


\subsection{Cómo aprovechar las oportunidades}

Se debe tener presente el aumento en la siembra de soja para efectuar las estimaciones del mercado de inoculantes y poder responder así a la mayor demanda de este insumo agropecuario.

El hecho de que algunos productores aun no utilizan inoculantes, brinda la oportunidad de recomendar nuestro producto a aquellos que sospechan de su efectividad ofreciendo una asociación en la siembra en donde AgroInvest participaría en una fracción igual a la que representan los inoculantes dentro del costo total de la campaña.

Si se mantienen las actuales condiciones en el mercado cambiario, se puede pensar en un futuro no muy lejano en incursionar en mercados externos, comenzando inicialmente en países limítrofes (especialmente Brasil).

\subsection{Cómo reducir las debilidades}

Dado que el producto aún no es conocido en el mercado se deberá invertir en publicidad para hacer llegar información acerca del inoculante a la mayor parte de los productores del mercado objetivo.

Se deberán contactar a distribuidores de distintos insumos agropecuarios ofreciendo un atractivo nivel de comisiones respecto a la competencia.

Para comenzar una relación con los proveedores se deberá realizar una investigación del mercado de cada uno de los insumos (especialmente de envases) comenzando la búsqueda en páginas web y siguiendo por distintas guías de empresas nacionales.

Pensando en permanecer en la frontera tecnológica, se deberán destinar fondos para asistir a seminarios y dedicar un tiempo importante a la investigación sobre nuevos desarrollos en el sector.

\subsection{Cómo evitar las amenazas}

Dado que las condiciones climáticas pueden afectar la zona objetivo, principalmente por abundantes lluvias que transformen áreas sembradas actuales en zonas de imposible siembra, la empresa deberá diversificar en el tiempo su mercado de destino para evitar bruscas fluctuaciones de demanda.

La volatilidad económica deberá ser muy tenida en cuenta a medida que avance el proyecto ya que si se modifican las condiciones actuales se deberá tener presente que la demanda puede caer; en este caso a partir de escenarios de mínima se deben manejar los niveles de producción para no stockear un producto que es perecedero.

El hecho que muchas empresas de gran tamaño no detenten una participación elevada en este mercado es una amenaza futura pero a partir de una buena relación precio-calidad se podrá reducir la posibilidad de ingreso masivo de las grandes empresas en el segmento objetivo. 


\section{SEGMENTACIÓN Y POSICIONAMIENTO}

\subsection{Segmentación}

Siguiendo a Kotler para proceder a la segmentación de un mercado se debe tener presente que en él conviven compradores que difieren en uno o más aspectos. Entre las divergencias que pueden observarse entre compradores, las más mencionadas son sus deseos, su poder de compra, su ubicación geográfica y sus actitudes y prácticas de compra.

Un primer paso para segmentar un mercado consiste en la identificación de las variables de segmentación. A partir de ello, se puede escoger el mercado en el cual debería operar la firma.

La identificación de las distintas variables que permiten la segmentación del mercado de inoculantes puede basarse en los resultados obtenidos de la encuesta. A partir de la misma fue posible hallar las siguientes variables: a) localización de la demanda, b) poder de compra, c) tipo de producto que prefiere, d) canal de distribución por el que accede al producto, d) atributos que valora el cliente.

Teniendo en cuenta los resultados de la encuesta se encontró que según la clasificación provista por Andreasen y Belk (1980) el productor agropecuario que utiliza inoculantes tiene un comportamiento de hogareño pasivo, es decir adquiere inoculantes al mismo proveedor de otros insumos agropecuarios, localizado en su ciudad de origen. Es por ello, que la segmentación geográfica que tomará la firma es su zona de influencia, es decir cercana a los distribuidores. En este sentido, el mercado objetivo serán los municipios bonaerenses linderos a la ciudad de Junín (incluido el municipio homónimo), además de departamentos del sur de la provincia de Santa Fe. ${ }^{15}$

En cuanto al poder de compra se observa que la mayoría de los potenciales consumidores, son de mediana escala. La segmentación en este sentido, tomará a los productores que siembren menos de 700 hectáreas.

Debido al tipo de producto preferido se encuentra que el inoculante líquido con fungicida es el preferido por lo cual se apuntará a dicho segmento.

La segmentación de mercado relacionada al canal de distribución que se escogerá será el de los distribuidores de todo tipo de insumos agropecuarios.

Respecto a los atributos que valora el cliente, se encuentra cierta homogeneidad en las preferencia: buena relación precio-rinde (muy asociado a la reputación de la empresa)-facilidad en el uso; aunque existe un segmento importante que prefiere sólo precios bajos ya que el rendimiento no varía demasiado con la aplicación de uno u otro inoculante. Se apuntará a este último segmento.

\footnotetext{
${ }^{15}$ Los municipios de Junín, General Pinto, General Villegas, Chacabuco, Carlos Casares, Mercedes, Bragado, General Arenales, Rojas, San Andrés de Giles, General Viamonte, Leandro N. Alem, 25 de Mayo, Salto, Nueve de Julio, Pergamino, Lincoln, Ameghino, Chivilcoy, Carmen de Areco en la provincia de Buenos Aires; y los departamentos de Castellanos y General López en la provincia de Santa Fe.
} 
En resumen, los consumidores que surgen de la segmentación de mercado son los localizados en los partidos linderos a Junín, que siembran menos de 700 hectáreas, que consuman inoculantes líquidos con incorporación de funguicida, que accedan al producto a partir de distribuidores de todo tipo de insumos agropecuarios con preferencias marcadas por el pago de un menor precio.

\subsection{Posicionamiento}

El posicionamiento puede ser entendido como el lugar que ocupa el producto, el servicio, o la empresa en la mente del consumidor. Si bien los inoculantes, debido a sus características físicas, parecen anodinos y con escasa posibilidades de efectuar una diferenciación. En esta sección se intentarán captar diversas variables que sean sujetas a diferenciación para, de este modo, lograr un posicionamiento de la firma dentro del segmento de mercado escogido.

Existen conceptos que deben tenerse presente a la hora de escoger el posicionamiento de una marca o empresa. ${ }^{16}$ Entre ellos se destacan los siguientes:

$\checkmark$ Posicionar significa recortar segmentos del mercado que necesiten o deseen cosas distintas de otros segmentos y construir un producto para adueñarse de esa diferencia.

$\checkmark$ El posicionamiento no se refiere al producto, sino a lo que se hace con la mente de los probables clientes o personas a las que quiere influir. Es esencialmente una estrategia de negocio, da la respuesta a la pregunta: ¿cómo diferenciarse de los demás?. Una vez que uno sabe quién es y qué lo diferencia del otro, todas las decisiones se simplifican.

$\checkmark$ El posicionamiento consiste en conformar la oferta de la compañía de manera que ocupe un lugar claro y apreciado en la conciencia de los consumidores meta.

Una vez definido el concepto de posicionamiento, la literatura se pregunta si el empresario debe destacar una o varias diferencias del producto a comercializar. Reeves ${ }^{17}$, en la década del '60 entendía que una compañía debía desarrollar una propuesta única de ventas (PUV) por marca y atenerse a ella. A medida que fue pasando el tiempo, se comenzó a pensar en una estrategia de posicionamiento doble, destacando dos cualidades del producto o posicionamiento triple, remarcando tres características diferenciales del bien o servicio a comercializar.

Intentando no cometer los errores comunes en la elección de un posicionamiento específico, tales como subposicionamiento (los clientes no llegan a conocer casi nada de la marca); sobreposicionamiento (el público puede tener una imagen demasiado reducida de la marca, es decir tal vez el producto tenga varias cualidades y solo se resalta una), posicionamiento impreciso (el cliente puede tener una idea borrosa de la marca); posicionamiento dudoso (el público no cree en la publicidad al confrontar calidad con precio), se analizarán diversas alternativas de diferenciación de producto de acuerdo a los atributos más valorados por los consumidores de inoculantes.

\footnotetext{
${ }^{16}$ Ver Kotler P.

${ }^{17}$ Ver Reeves R.
} 
Para ello se procederá a construir diversos mapas de posicionamiento, teniendo en cuenta características particulares factibles de diferenciar y, llegar de ese modo, a la elección de una diferenciación de producto acorde con las cualidades y potencialidades de la firma.

GRAFICO No 14

MAPA DE POSICIONAMIENTO: CALIDAD PERCIBIDA Y PRECIO

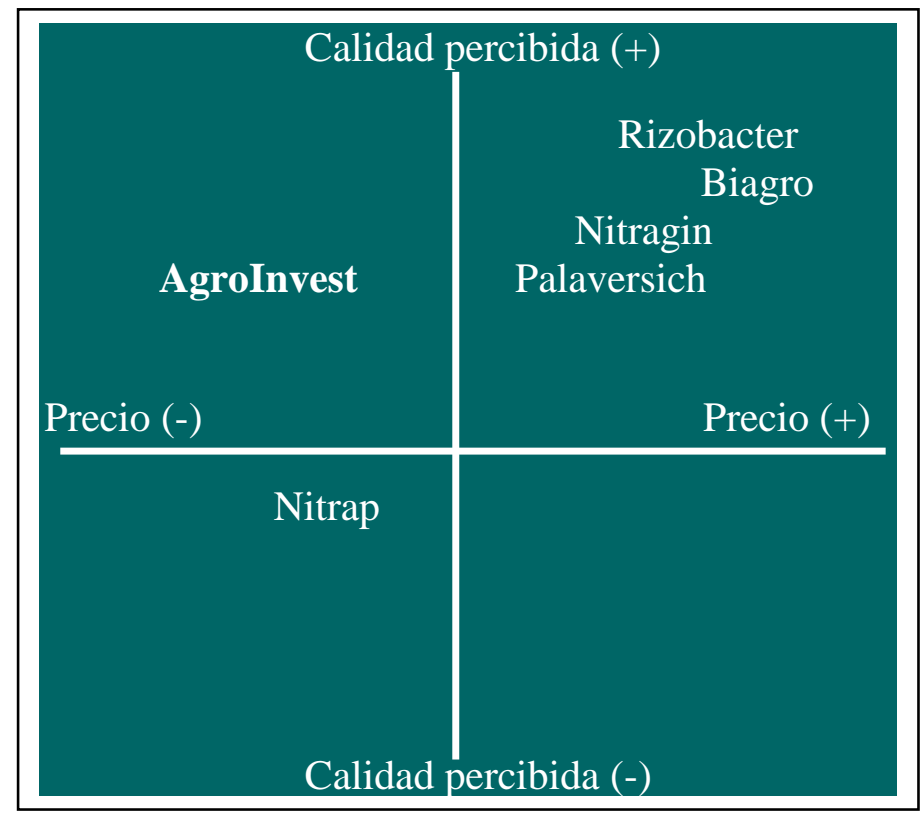

En este primer mapa del mercado es posible ubicar a AgroInvest en un nicho que no es ocupado por el resto de las empresas. El segmento escogido es el de precios bajos y una calidad percibida intermedia que podría ir mejorando a medida que las inversiones en investigación y desarrollo rindan sus frutos.

GRAFICO $\mathbf{N}^{\circ} 15$

MAPA DE POSICIONAMIENTO: RENDIMIENTO Y PRECIO

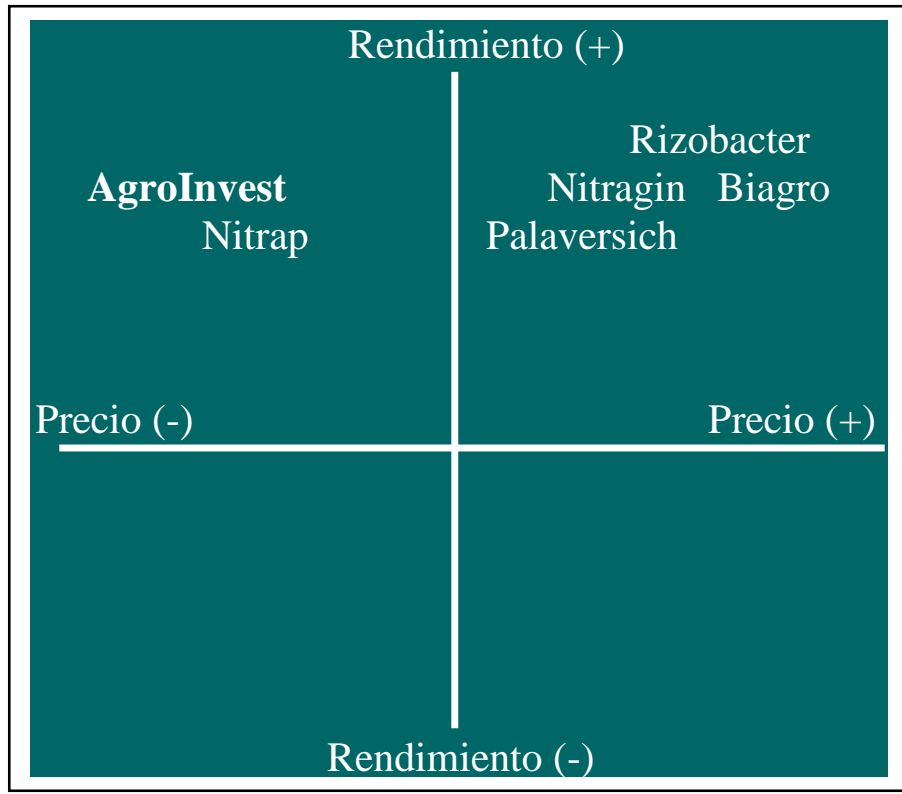


Si bien existe una reputación de firmas líderes en el mercado, la misma ha sido ganada por permanencia y por efectuar un posicionamiento de su marca remarcando la calidad de sus productos. Diversos estudios indican que no existen diferencias sustanciales de rinde relacionadas a la aplicación de un inoculante en particular. En el mapa anterior se observa que AgroInvest permanece en su segmento de precios bajo y asegurando un rinde similar al de las empresas percibidas como de mejor calidad.

\section{GRAFICO $\mathrm{N}^{\circ} 16$ \\ MAPA DE POSICIONAMIENTO: FACILIDAD EN EL USO Y PRECIO}

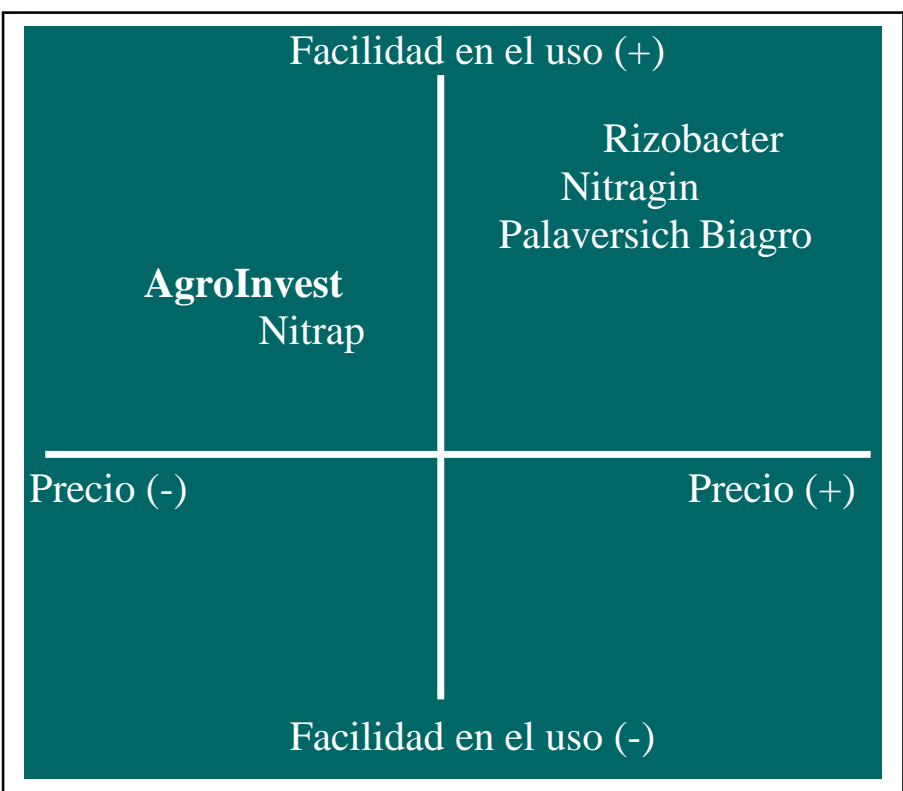

La mayor parte de las firmas del sector han invertido para mejorar la facilidad en la aplicación de los inoculantes. Si bien este factor es de relevancia para los consumidores, la variable precio es más significativa a la hora de escoger un inoculante. Es por ello, que se recomienda en una primera instancia no producir una diferenciación en este sentido.

\section{GRAFICO $N^{\circ} 17$ \\ MAPA DE POSICIONAMIENTO: CANALES DE DISTRIBUCION Y PRECIO}

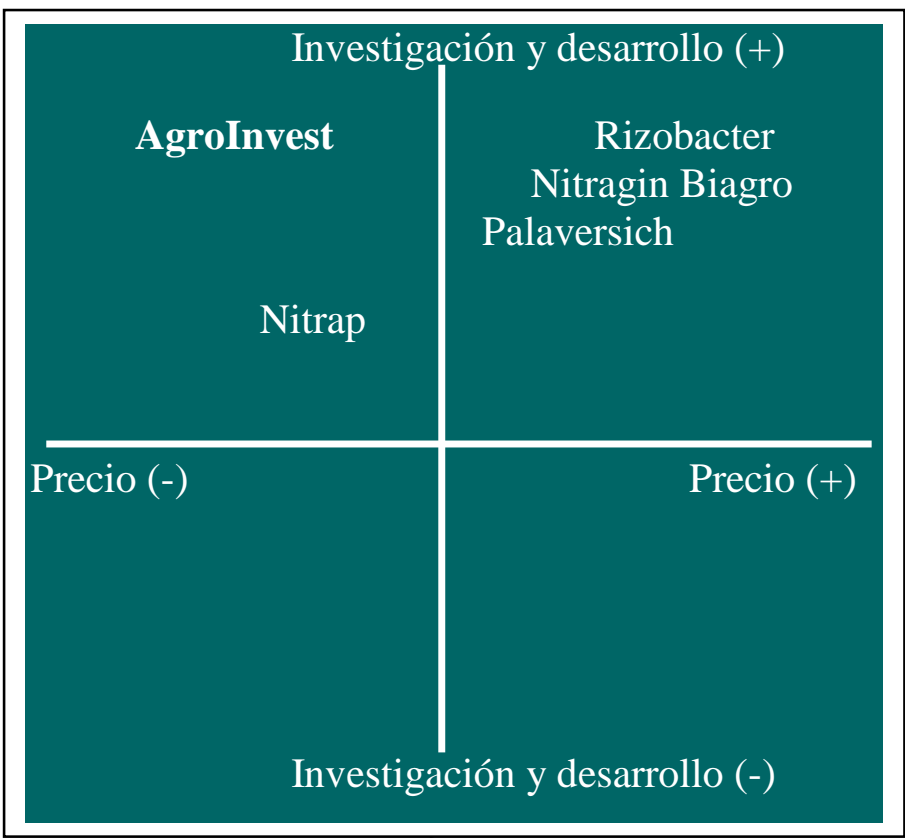


La investigación y el desarrollo es una de las características que hacen a la reputación de una firma a lo largo del tiempo. Se recomienda diferenciarse de las firmas que venden a precios bajos a partir de un posicionamiento de AgroInvest como una de las líderes en investigación y desarrollo.

De acuerdo al análisis efectuado es posible recomendar a AgroInvest que efectúe un posicionamiento triple haciendo hincapié en elevados rendimientos a precios bajos posibilitados por la constante innovación a partir de la investigación y el desarrollo.

\section{ESTRATEGIA DE MARKETING MIX DE AGROINVEST}

En esta parte del trabajo se desarrollará la estrategia de marketing mix de la firma AgroInvest. Antes de abordar la misma es necesario comprender las diversas etapas por las que atraviesa el ciclo de vida de un producto para, de ese modo, elaborar una estrategia para determinadas fases: ${ }^{18}$

1. Introducción o lanzamiento: es un período de crecimiento lento de las ventas, mientras se introduce el nuevo producto en el mercado.

2. Crecimiento: es un período de rápida aceptación del mercado y aumento substancial de las utilidades.

3. Madurez: es un período en el cual las ventas y el crecimiento se hacen lentos, debido a que el producto ha logrado la aceptación de la mayoría de los compradores potenciales. Las utilidades se estabilizan o declinan por el aumento de los gastos de mercadotecnia para defender al producto de la competencia.

4. Declinación: es el período en el cual las ventas muestran un fuerte descenso y las utilidades desaparecen.

Si bien, no existe precisión en la literatura acerca de la duración de cada una de las etapas mencionadas, se coincide en señalar que el ciclo de vida difiere según el producto que se trate. Si bien la dinámica del mercado agropecuario dificulta la justificación de un período de tiempo para cada una de las etapas, aquí se intentará definir un cronograma del ciclo de vida de un insumo específico como el inoculante.

GRÁFICO No 18

CICLO DE VIDA DE PRODUCTOS DE AGROINVEST

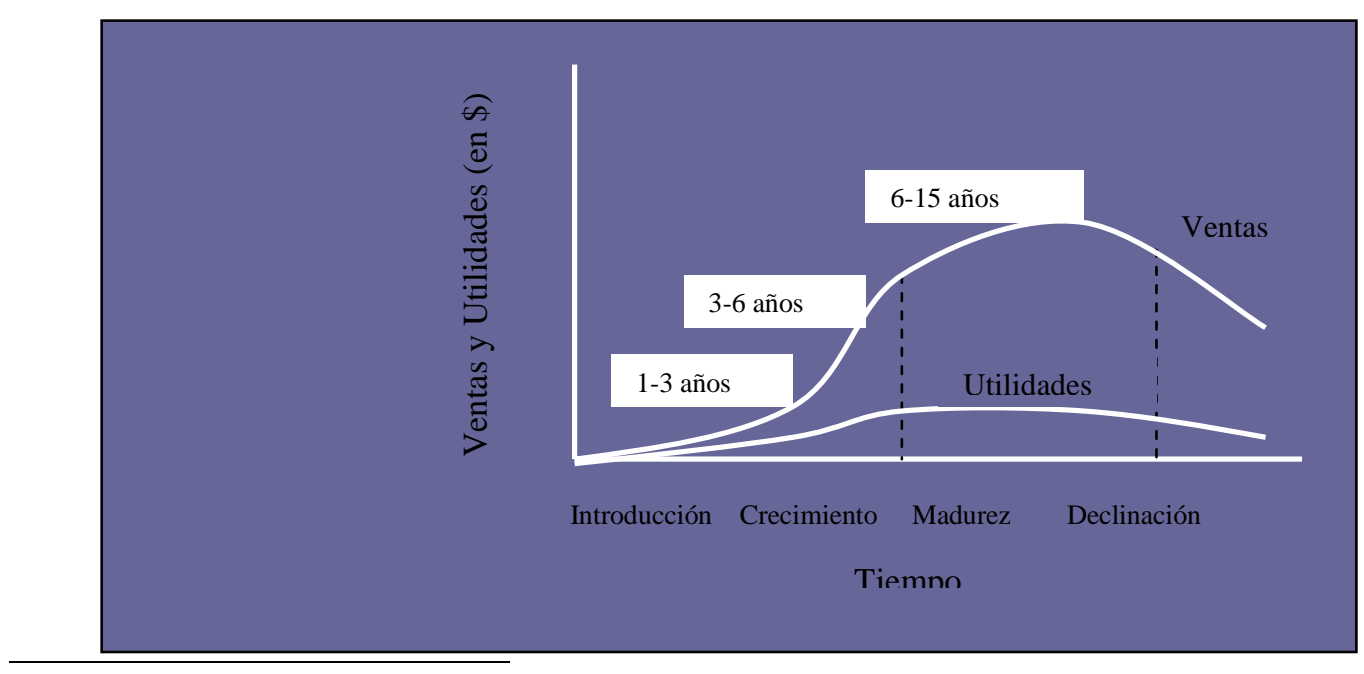

${ }^{18}$ Ver Levitt, $\mathrm{T}$. 
En un mercado tan dinámico como el agropecuario en Argentina, es posible encuadrar la etapa de lanzamiento en los primeros 3 años de vida de la firma, mientras que la etapa de crecimiento puede estimarse en los 3 años siguientes y la de madurez en el período que va desde los 6 a los 15 años. En tanto que la fase de declinación iniciaría a partir del $15^{\circ}$ año de operación de la firma.

A diferencia en lo observado en la literatura, en el gráfico anterior puede apreciarse que en el producto considerado no se prevén utilidades negativas en la primera etapa, debido a que los gastos de introducción del producto no serán demasiado elevados en la primera etapa.

Teniendo en cuenta el ciclo de vida del producto a comercializar, a continuación se abordará una estrategia de marketing mix para la etapa de introducción o lanzamiento del producto.

\subsection{Estrategia de Producto en la Etapa de Introducción}

Antes de lanzar un producto de las características de un inoculante es necesario conocer los aspectos legales necesarios para registrar el producto. Es por ello que en primer lugar se tendrá en cuenta esta cuestión. Una vez comprendidos los condicionantes legales es posible definir cuestiones referidas con el nombre de la firma, la marca del (de los) producto(s), el tipo de producto, el envase, el packaging, etc.

Entre los aspectos legales el recorrido para la inscripción de una empresa y producto es el siguiente. En primer lugar se debe inscribir la sociedad en el Registro Provincial de Personas Jurídicas; en segundo lugar se requiere registrar el producto en el SENASA y; por último se necesita patentar el producto en el Registro Nacional de Propiedad Industrial.

Por ende el primer paso consistió en la elección de un nombre para la firma. Se evaluaron varios nombres y, dado que el posicionamiento de la firma tiene entre sus aspectos relevantes apuntar a un segmento del mercado agropecuario que privilegia la investigación y desarrollo, se pensó en la idea de combinar ambos términos para decidir el nombre de la empresa. En primer lugar se coincidió en llamar a la compañía Agro Lab, pero como existía una firma con un nombre similar, el Registro Provincial de Personas Jurídicas indicó que se debería escoger otro nombre. Así, luego de deliberar con los socios, se propuso Agro Invest, ya que de ese modo se combina el sector de actividad en el que operará la firma (en un sentido amplio dejando espacio para la producción de todo tipo de inoculantes) y el término Invest denota tanto investigación como su significado en inglés inversión.

Una vez obtenida la aprobación del nombre de la empresa, se procedió a registrar el producto en SENASA. Según la Resolución RY 310 del año 1994, para habilitar la producción de inoculantes se debe cumplir con ciertos requisitos que se exponen a continuación:

Se deben presentar muestras del producto terminado, semillas para las cuales es específico, y el/los antisueros para el/los microorganismos presentes en el producto y/o técnicas alternativas de reconocimiento.

$\checkmark$ Todo producto con fecha de vencimiento superior a seis meses deberá ser elaborado en base de soporte estéril e indicar el método de esterilización con antecedentes y 
bibliografía. En aquellos casos que en el marbete se recomiende almacenar el producto a temperatura ambiente, las pruebas de supervivencia hasta la fecha de expiración se llevarán a cabo a temperaturas de hasta $40^{\circ} \mathrm{C}$ para cubrir las distintas zonas ecológicas del país. El tiempo entre la inoculación y la siembra será evaluado de acuerdo a las características de cada producto.

$\checkmark$ Las firmas elaboradoras de fertilizantes biológicos deberán enviar al departamento técnico del Instituto Argentino de Sanidad y Calidad Vegetal, dentro de los quince días de terminada la elaboración, un resumen del protocolo de la misma en el que se consignará, fecha de elaboración de cada lote, volumen del mismo en kilogramos y en unidades envasadas, especificidad del producto y fecha de vencimiento.

$\checkmark$ Los fertilizantes biológicos deberán cumplir con las siguientes especificaciones del marbete: ser efectivos para la/s especie/s vegetal/es que se consigne/n, proveyendo al vencimiento la cantidad de microorganismos viables necesarios para obtener una acción efectiva. en el caso de los inoculantes de leguminosas deben proveer, para semilla tipo soja, el equivalente a no menos de 80.000 bacterias viables específicas por semilla. Para productos recién elaborados sobre base no estéril, la cantidad de bacterias viables específicas deberá ser superior a uno por diez a la novena por gramo de producto.

$\checkmark$ Los datos de marbete variables son: la fecha de vencimiento y el número de lote; éstos serán colocados en forma visible y por métodos inalterables, como parte integrante del envase.

Ya registrado el producto se procedió a patentar la marca en el Registro Nacional de Propiedad Industrial. La marca, se constituye en otro de los elementos centrales de la estrategia de producto. En este caso, se pensó en diversas combinaciones relacionadas con las características físicas del producto (en donde la bacteria es el principal insumo) y el aporte que realiza (nitrógeno). Luego de analizar diversas combinaciones y comparando con las marcas existentes en el mercado (evitar semejanzas), se llegó a la conclusión que no existía la posibilidad de combinar ambos elementos. Es por ello, que se reconsideró el caso y se ha concordado con los socios en que la marca debe tener un fuerte impacto sobre los potenciales compradores demostrando cierta fortaleza. Es por ello que se decidió denominar a los productos con el nombre comercial de Full-Bacter. En este caso, se privilegió escoger un nombre que se asocie al poder de rinde del inoculante (full) combinado con uno de sus componentes (la bacteria). Así se llegó a la marca Full-Bacter para la primera línea de inoculantes que lanzará la firma al mercado.

En cuanto a las características del producto, en base a la encuesta preparada para la elaboración de este trabajo y a lo recogido en diversas charlas con productores del sector, se coincidió en la producción de inoculante líquido en base acuosa, en cuya formulación intervengan:

- Bacterias fijadoras de nitrógeno específicas para la fijación simbiótica de nitrógeno en soja (Bradyhizobium sp.). 
- Aditivos cuya función es la de prolongar la viabilidad celular durante más tiempo dentro del envase, y proteger las bacterias durante el período crítico entre la inoculación y la siembra.

- Adhesivos para favorecer la adherencia del inoculante a la semilla.

A su vez el producto debe contener una cantidad de bacterias muy superior a la exigida por la legislación que regula la producción de este insumo (80.000 bacterias por semilla).

Respecto a los insumos a utilizar se decidió adquirir las bacterias y medios de cultivo en el INTA y la turba a un productor de la provincia de Tierra del Fuego que dispone de una planta en Capital Federal. En cuanto a los envases, los oferentes se encuentran bastante atomizados y en una primera etapa se ha decidido adquirir los mismos a una empresa local con una capacidad de producción muy importante, ya que a partir de una relación más estrecha será posible adaptar los pedidos a las necesidades de la firma.

El envase, además de indicar la marca del producto, contendrá fecha de vencimiento, número de partida (ante cualquier duda o reclamo, este número le permitirá a la empresa seguir la trazabilidad del lote para poder detectar el problema) y recomendaciones de uso.

El envase primario será un sachet que contenga una dosis para inocular $50 \mathrm{~kg}$. de semilla, mientras que el envase secundario será una caja que contenga 25 sachets.

La estrategia de producto no debe centrarse solamente en las características tangibles del mismo sino también en otros servicios que debe brindar la firma. Entre ellos, se destacarán un sello de garantía del producto, se priorizará la entrega en los tiempos pactados con los distribuidores o productores y el servicio de posventa se asegurará mediante la incorporación de una línea telefónica directa con un soporte técnico que asesorará al productor para satisfacer todas las consultas que puedan surgir respecto a la aplicación del producto.

En este trabajo no se considerará el mix de productos ya que en la etapa de lanzamiento sólo se piensa incursionar en el mercado de inoculantes con un solo tipo de producto. De igual modo es importante decir que la dinámica del mercado puede hacer variar esta estrategia y considerar la posibilidad de ampliar la gama de productos ofrecidos. 


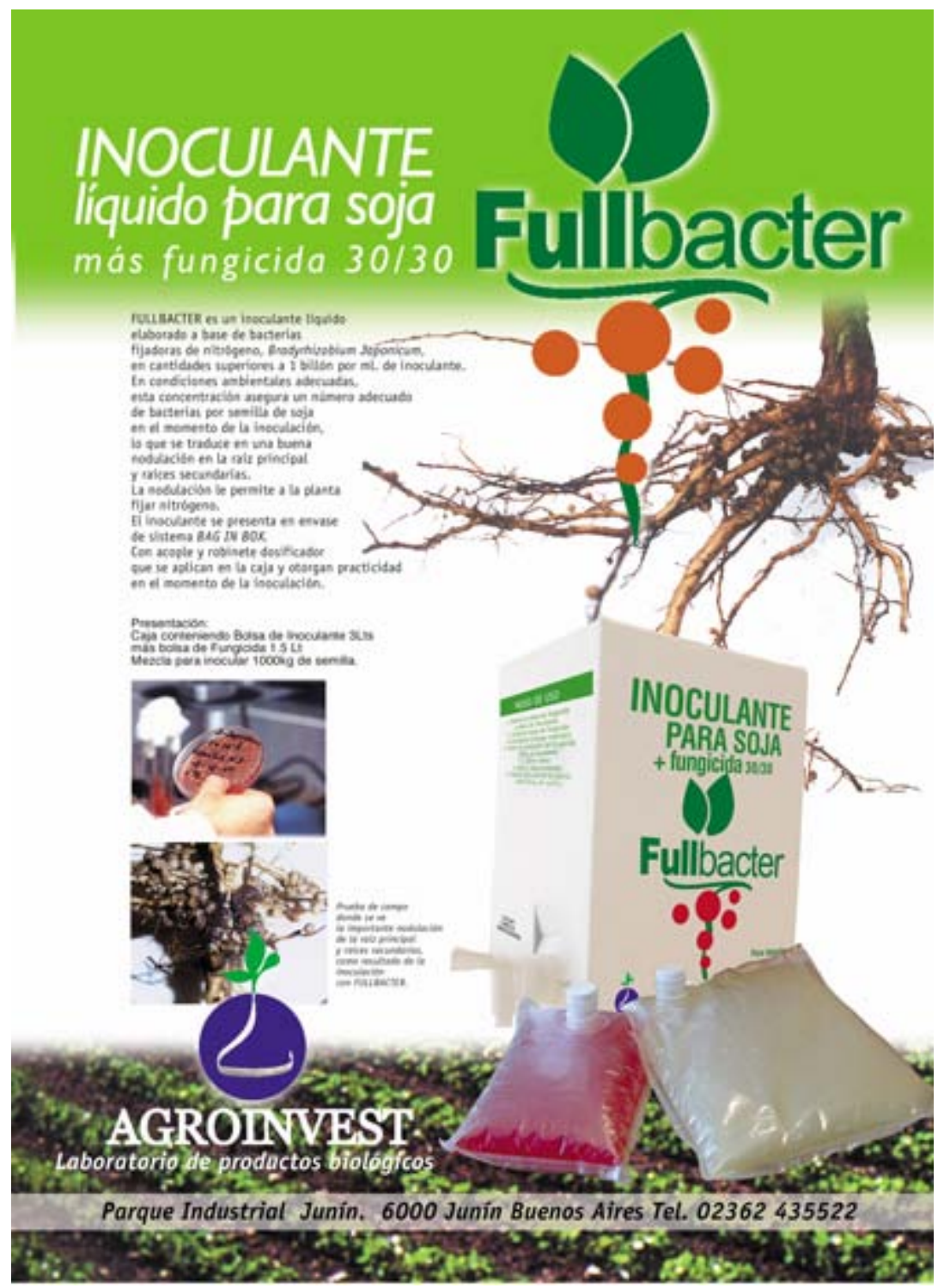

Como se aprecia en la imagen anterior, el inoculante para soja se vende junto a un fungicida. El inoculante FULLBACTER es un producto formulado con la más alta tecnología en procesos microbiológicos.

Las buenas prácticas de elaboración, la tecnología disponible hacen un producto de excelente calidad en número de bacterias, como en viabilidad.

Esto es llevado a cabo por medio de los protectores bacterianos más modernos. La ventaja sobre la gran mayoría de los inoculantes del mercado es que no es mixto (No posee turba), con lo cual es mejor la homogeneización y adhesividad (por no quedar las bacterias retenidas en mayor concentración en la pequeña proporción de turba, 10\%) Facilitando el manejo a campo ya que se evitan obstrucciones y aglomeramientos en el dosificador.

El packaging apunta a una moderna presentación que permita mezclar muy fácilmente los componentes logrando una preparación homogénea, lista para aplicar sobre semillas.

En este sentido será muy importante utilizar envases con tecnología BAG IN BOX como parte de un concepto diferente en el envasado de líquidos. Fabricados con 
materiales que permiten un mejor intercambio gaseoso con el medio ambiente; práctico, seguro, liviano y muy fácil de reciclar.

El accesorio para acople entre bolsas y la válvula expendedora otorgarán gran practicidad en el mezclado y dosificación del producto, permitiendo obtener las dosis exactas que asegurarán la rápida infección de las semillas con una temprana nodulación.

Dado que los socios de la empresa cuentan con una moderna flota de camiones, como camionetas para que el producto esté puesto en destino, en tiempo y forma. Se sugiere que se conformen pallets de 100 cajas, en donde cada caja contiene 20 dosis. Así cada camión podrá transportar 24 pallets, es decir 48.000 dosis de inoculantes.

En la figura siguiente se muestra el esquema propuesto.
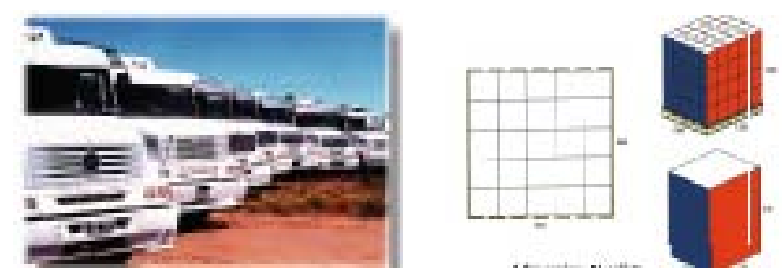

\subsection{Estrategia de Precio en la Etapa de Introducción ${ }^{19}$}

Dentro de las estrategias de mercadotecnia enunciadas por la literatura existen distintas variantes para introducir un producto al mercado y en ellas, el precio es una variable clave que varía según la estrategia escogida.

$\checkmark$ Estrategia de espumación lenta: consiste en el lanzamiento de un producto a un precio elevado y con poca promoción.

$\checkmark$ Estrategia de penetración rápida: consiste en el lanzamiento de un producto a un precio bajo y con fuertes erogaciones en promoción.

$\checkmark$ Estrategia de penetración lenta: consiste en el lanzamiento del producto a precio bajo con bajo nivel de promoción.

Por otra parte, existen diversas formas de fijación de precios:

$\checkmark$ Lo más usual es agregar un margen bruto estándar al costo del producto.

$\checkmark$ La fijación de un precio para obtener un margen determinado

$\checkmark$ La fijación de precios por el valor percibido del producto por parte del comprador

$\checkmark$ La fijación de precios según el índice corriente: es decir basándose en gran parte en los precios de la competencia.

La estrategia recomendada para la firma es una de penetración lenta y fijación de precios teniendo en cuenta los tres últimos métodos. Respecto a la penetración lenta, es deseable debido a que la producción potencial no permitiría abastecer un proceso de crecimiento de ventas acelerada.

Respecto a la combinación de los tres métodos de fijación de precios, la explicación a esta elección es la siguiente: el valor percibido por el productor en un contexto como el

\footnotetext{
${ }^{19}$ Ver Porter (1990).
} 
actual en los cuales el precio de la soja está en niveles históricos elevados es mucho más elevado que el que representan los costos de producción. A su vez, la competencia toma en cuenta el valor percibido, vendiendo sus productos muy encima de sus costos. Es por ello que se recomienda fijar un precio $15 \%$ inferior al de la competencia, asegurando de igual modo una rentabilidad adecuada y satisfaciendo el valor percibido por los productores.

En la etapa de lanzamiento la táctica de precios será la siguiente:

$\checkmark$ En primer lugar, se hará descuento de $10 \%$ a los distribuidores que superen una compra de 2.500 dosis (100 cajas).

$\checkmark$ En las ventas a productores en forma directa se le hará un descuento a aquellos que recomienden a un productor amigo la adquisición del inoculante. En este caso, la operatoria se instrumentará de la siguiente manera: se abrirá una línea de consultas en un período comprendido desde los 60 días de la siembra hasta el fin de la misma. Se tomarán los datos de los consultados. A los productores que adquieran más de 250 dosis y recomienden a un amigo la compra de inoculantes y éste efectúe la compra por una cantidad igual o superior al primer consumidor, se le hará un descuento del 15\%, mientras que al cliente que fue recomendado por el amigo se le descontará un 10\% de su compra. Todos estos descuentos serán por pago al contado (50\%) y a 30 días (el resto de la compra menos el descuento respectivo).

$\checkmark$ Cuando el pago se efectúe a cosecha, el productor no gozará de ningún tipo de descuento.

La estrategia enunciada será la propuesta para el primer año de operaciones. En el segundo y tercer año, se recomienda ir adaptando los precios a los de la competencia a medida que la reputación en el mercado lo vaya permitiendo. A su vez en las siguientes campañas se harán los mismos descuentos enunciados para el primer año y se adicionarán bonificaciones para aquellos productores que ya hayan adquirido el producto en forma directa en la empresa.

\subsection{Estrategia de Distribución en la Etapa de Introducción}

La literatura ${ }^{20}$ identifica distintos niveles de canales de distribución. Cada intermediario que interviene en alguna función para acercar el producto al consumidor final constituye un nivel del canal. Según el mercado que se trata pueden existir diversos niveles de canales que a continuación se exponen:

$\checkmark$ Canal nivel cero: es también llamado canal de mercadotecnia y consiste en la venta directa del fabricante al consumidor final. Las cuatro principales variantes de este método son la venta de puerta en puerta, demostraciones, por correo y en los comercios del fabricante.

$\checkmark$ Canal de un nivel: contiene un intermediario de ventas.

$\checkmark$ Canal de dos o más niveles: contiene dos o más intermediarios, que en los mercados de consumo, son en general un mayorista y un minorista.

\footnotetext{
${ }^{20}$ Ver Kotler P. (1991).
} 
A su vez debe seleccionarse la cantidad de intermediarios de acuerdo a la estrategia de inserción de la firma. Entre ellos se destacan:

$\checkmark$ Distribución intensiva: es decir abastecer el producto en numerosas plazas.

$\checkmark$ Distribución selectiva: emplear más de uno pero no todos los intermediarios dispuestos a manejar un producto en particular.

$\checkmark$ Distribución exclusiva: sólo ciertos distribuidores pueden comercializar los productos de la compañía. Con frecuencia a este método de distribución suele acompañar el convenio de exclusividad.

Teniendo en claro estos conceptos, la estrategia recomendada para la distribución de los productos es a través de canales de nivel cero, es decir vender desde la firma utilizando para la entrega vehículos de terceros contratados y de nivel dos para lo cual se recomienda una estrategia de distribución exclusiva para el primer nivel (dirigir las ventas a uno o pocos distribuidores de nivel uno) e intensiva para el segundo (el canal uno se encargaría de imponer el producto en la mayoría de los distribuidores) .

Dado que en el mercado existe una cantidad importante de distribuidores atomizados a lo largo de toda la región sojera que venden todo tipo de insumos agropecuarios, se intentó contactar a firmas que venden a dichos distribuidores otro tipo de productos (principalmente semillas) para generar alguna relación de exclusividad.

Existen avanzadas negociaciones para que una importante cerealera del país comercialice los inoculantes producidos por Agro Invest. Las tratativas avanzan en dos direcciones; por un lado se considera la posibilidad de vender con marca propia y que la cerealera presente el producto Full-Bacter a sus distribuidores dispersos por todo el país $\mathrm{y}$, la segunda consiste en vender el inoculante sin marca y que la cerealera incorpore la suya en el inoculante. La cerealera en cuestión tiene una importante reputación en el mercado, lo cual permitirá una mayor inserción inicial del producto.

De concretarse dicha operación, durante la primera campaña se estaría al límite de la capacidad instalada con lo cual el remanente a vender podría ser comercializado desde la propia planta productora, evitando de esa manera incurrir en costos de transporte y en pérdidas en el total de ventas por el impacto de las comisiones que cobran distribuidores externos. Para el futuro, cuando la capacidad de producción se expanda, se recomienda continuar contactando a importantes cerealeras para que éstas se encarguen de efectuar las ventas.

La política enunciada está acorde con la visión de la firma ya que la reducción de tiempos y dinero para la distribución de sus productos permitirá concentrar esfuerzos en la investigación y el desarrollo en pos de lograr un mejoramiento continuo de la calidad de los productos a comercializar.

Hasta aquí se presentó la estrategia de distribución para la etapa de lanzamiento de producto, aunque no se descarta que en el futuro próximo se comience a exportar este insumo a países productores de soja como Brasil, EEUU y China. En caso de decidir la venta externa se deberá contactar a distribuidores de dichos países, una vez analizada toda la legislación de los países de destino (barreras legales, fitosanitarias, administrativas, etc.). 


\subsection{Estrategia de Comunicación y Promoción en la Etapa de Introducción}

En el proceso de comunicación existen diversos elementos a tener en cuenta ${ }^{21}$ para que el mensaje que pretende enviar el emisor del mismo (la firma) llegue a los receptores, es decir a quienes se dirija el mensaje (ej. consumidores o distribuidores). Entre ellos se encuentran la codificación (proceso de expresar el pensamiento en forma de símbolos), los medios (canales de comunicación por los cuáles se mueve el mensaje del emisor al receptor), desciframiento (proceso por el cual el receptor asigna un significado a los símbolos transmitidos por el emisor), respuesta (reacciones del receptor después de estar expuesto al mensaje), retroalimentación (es la parte del receptor que éste comunica al receptor) y ruido (es la estática o distorsión no planeada que tiene lugar durante el proceso de comunicación).

Además de conocer los distintos elementos que intervinientes en el proceso de comunicación existen diversos pasos a tener en cuenta para que el mismo sea eficaz: a) identificación de la audiencia meta; b) determinación de los objetivos de la comunicación; c) diseño del mensaje; d) selección de los canales de comunicación; e) distribución del presupuesto total de promoción; f) decisión acerca de la mezcla de promoción; g) medición de los resultados de la promoción; h) administración y coordinación de todo el proceso de comunicación de la mercadotecnia.

A continuación se planteará la estrategia propuesta a la firma Agro Invest para comunicar su producto teniendo en cuenta los ocho pasos mencionados.

Respecto a la identificación de la audiencia meta serán los productores agropecuarios que siembran soja y los distribuidores de todo tipo de insumos agropecuarios.

La determinación de los objetivos de la comunicación están referidos a la respuesta deseada de la audiencia meta. En este caso particular el objetivo para el primer año de operación de la firma será poner en conocimiento de la audiencia meta la existencia de la empresa y el producto. A medida que pasen los años y se amplíe la capacidad de producción, se debe generar que el producto sea preferido al de la competencia y convencer a la audiencia meta para adquirir el producto.

Para el diseño del mensaje se debe elaborar en primer lugar el contenido del mensaje. El mismo debe apuntar a un llamado de tipo racional, es decir apelando al propio interés de la audiencia meta. Luego se debe pensar en la estructura del mensaje, en este caso se recomienda que el mismo llegue a una conclusión por si solo y no que la audiencia deba hacer un esfuerzo para comprender el mensaje. También se debe tener en cuenta el orden de presentación, exponiendo los argumentos más sólidos al comienzo del mensaje. Respecto al formato del mensaje inicialmente se propone presentar el logo con claridad con colores que distingan claramente al producto de la competencia. La fuente del mensaje debe ser una que genere atractivo y brinde credibilidad al producto.

Entre la selección de los canales de comunicación, se proponen unos de carácter impersonal: a) que el propio envase comunique sobre las bondades del producto, b) publicidad estática en las rutas, c) publicidad en autos que compitan en las categorías de Turismo Carretera y TC Pista. Por el lado de los canales personales, con la estrategia de

\footnotetext{
${ }^{21}$ Ver Kotler P.
} 
precio enunciada también se prevé que los propios productores y los distribuidores se vean incentivados a comunicar sobre las ventajas de la utilización de este insumo agropecuario.

En cuanto a la fijación del presupuesto total de promoción, se recomienda el método de gasto factible, es decir decidir el presupuesto de acuerdo a lo que pretende gastar la firma. De todos modos también se debe evaluar la alternativa del método de paridad competitiva para tener una llegada similar a la de la competencia.

La decisión sobre la mezcla de promoción debe contemplar cuatro aspectos de la promoción: publicidad, promoción de ventas, propaganda y fuerza de ventas. Para ello hay que entender que la publicidad ofrece una razón para comprar mientras que la promoción de ventas brinda un incentivo. Partiendo de la base que en la etapa de lanzamiento la relación costo-eficacia de la publicidad y la propaganda son elevados, se recomienda brindar más importancia a la promoción de ventas (descuentos por compras ya citados, bonificaciones por comercialización, competencias de ventas entre distribuidores, etc.) mientras que en alguna etapa posterior se deberían incrementar los gastos en publicidad, propaganda y promoción de la fuerza de ventas (concursos, competencias de ventas, etc.).

La evaluación de los resultados de la promoción pueden obtenerse a partir de la consulta a los clientes que adquieren el producto directamente a la firma respecto a cuestiones referidas a cómo conoció el producto. De allí se podrá definir un nuevo mix de promoción en futuras campañas de ventas.

En lo referente a la administración y coordinación del proceso de comunicación se debe tener en cuenta que el inoculante se utiliza en una época del año bien precisa, entre septiembre y noviembre cuando se siembra la soja. Es por ello que los mensajes deben emitirse en un período no superior a 40 días antes del comienzo de la siembra.

En definitiva, en el primer año de operación de la firma se privilegiará una estrategia de comunicación que apunte a la presentación en el mercado de la firma recordando la estrategia de penetración lenta sugerida anteriormente. Para ello, los medios que acerquen el mensaje a los receptores deben ser el propio envase, estáticas en las rutas y en autos de competición. En ese mismo año, se comunicará a los clientes que adquieran el producto directamente en la firma y a los distribuidores sobre las bondades del producto y que el mismo será vendido a un precio bajo debido a los beneficios otorgados por la innovación en el desarrollo del producto durante varios años. Es decir, la publicidad será selectiva y de escaso costo, mientras que los esfuerzos se centrarán en la fuerza y promoción de venta.

Para los siguientes años se recomienda ampliar la difusión comenzando 40 días antes de la siembra, es decir a fines de julio y concluyendo a mediados de noviembre con presencia en revistas especializadas y programas de radio que anuncien información referida al agro o aquellos que se dirijan a una fracción importante de los productores agropecuarios (especialmente emisiones de automovilismo nacional). 


\section{MERCADO POTENCIAL}

\subsection{Mercado actual de inoculantes en el segmento objetivo}

El análisis del mercado actual, proyectado y las ventas de la empresa se realizarán sobre la base de datos existentes de área sembrada de soja en los municipios escogidos en la segmentación de mercado.

Una breve reseña de la superficie sembrada de soja permitirá cuantificar el mercado de inoculantes en el país y la región. Como se observa en el Gráfico siguiente, el área sembrada de soja se fue incrementando a lo largo de los últimos años, con un crecimiento cercano al 100\% entre los años 1989 y 2003, es decir cerca del 6\% de crecimiento promedio anual.

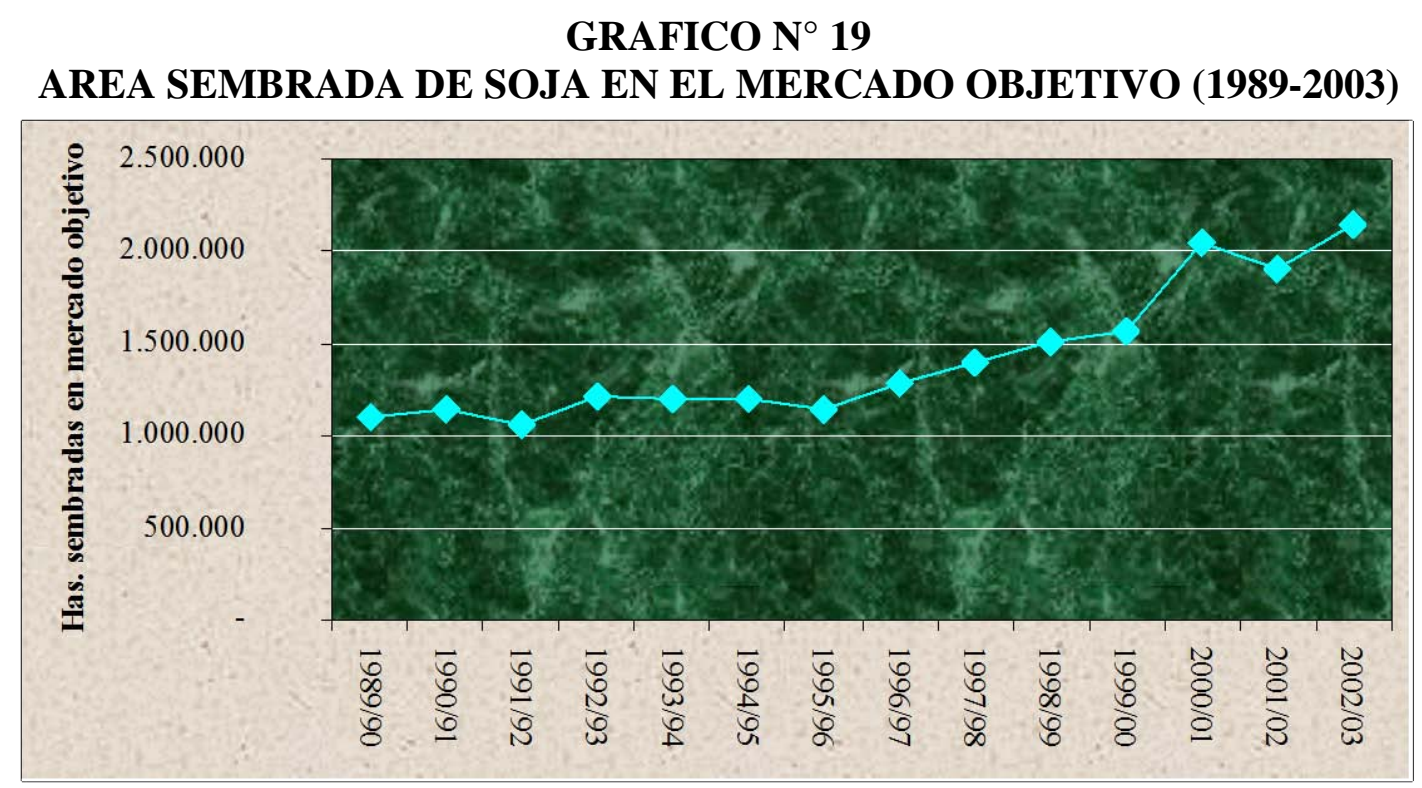

Fuente: SAGPyA.

Asimismo, la utilización de inoculantes fue creciendo a medida que la apertura de la economía demandaba mayores inversiones en tecnología agropecuaria. Teniendo en cuenta que por cada ha. sembrada se utilizan aproximadamente 320 grs. o centímetros cúbicos de inoculante y considerando el porcentaje de utilización de inoculantes sobre el total de has. sembradas, se obtiene:

$\mathrm{Ui}(\mathrm{ha})=\% \mathrm{U} * \mathrm{I}(\mathrm{ha})$, donde $\mathrm{Ui}(\mathrm{ha})$ es la utilización de inoculante por ha. en promedio sobre el total sembrado, \%U es el porcentaje de has. sembradas que utilizan inoculante e I(ha) es el inoculante necesario para sembrar una hectárea de soja. Para clarificar la ecuación mencionada basta con un ejemplo númerico: para la siembra 200203, el porcentaje de has. sembradas de soja en que se utilizó inoculantes fue de $75 \%$, a esto se lo multiplica por la cantidad de inoculante necesario para cada ha., se obtienen 240 grs. o centímetros cúbicos promedio por cada ha. sembrada $(0,85 * 320)$. 
GRAFICO $\mathbf{N}^{\circ} 20$

UTILIZACION DE INOCULANTES

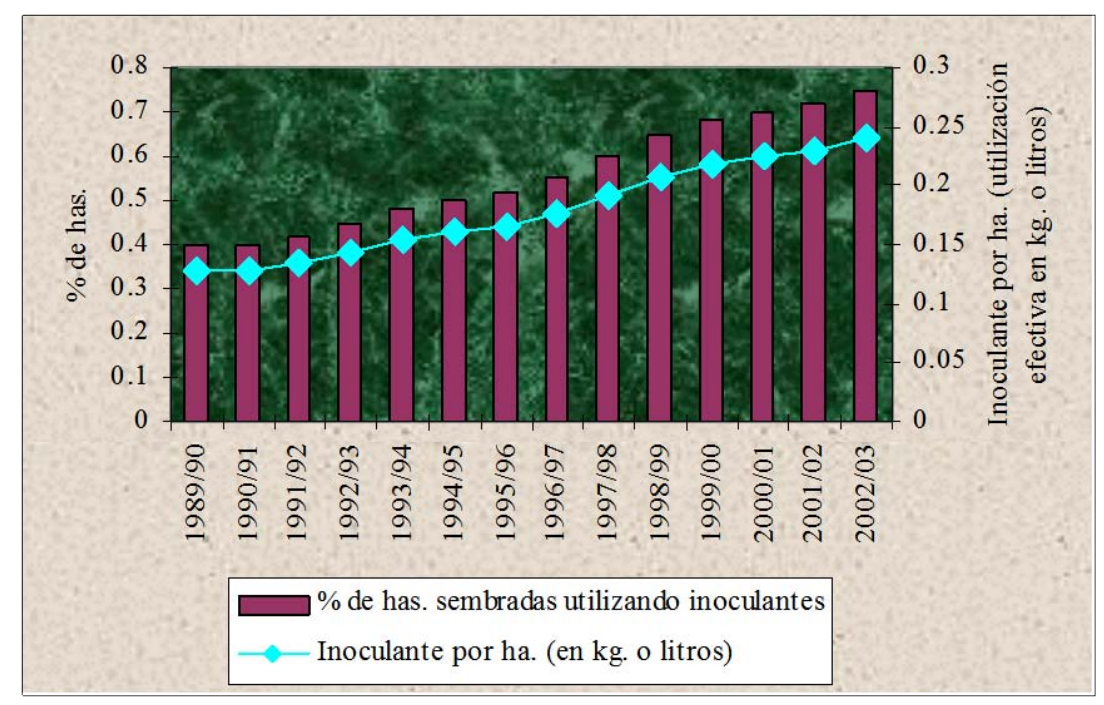

Fuente: elaboración propia en base a SAGPyA y Revista Márgenes Agropecuarios.

Teniendo en cuenta el mayor grado de utilización de inoculantes sumado a la mayor superficie sembrada se llega a que si se mide por kg. o litros utilizados más que se triplicó la utilización de este insumo a lo largo de la década.

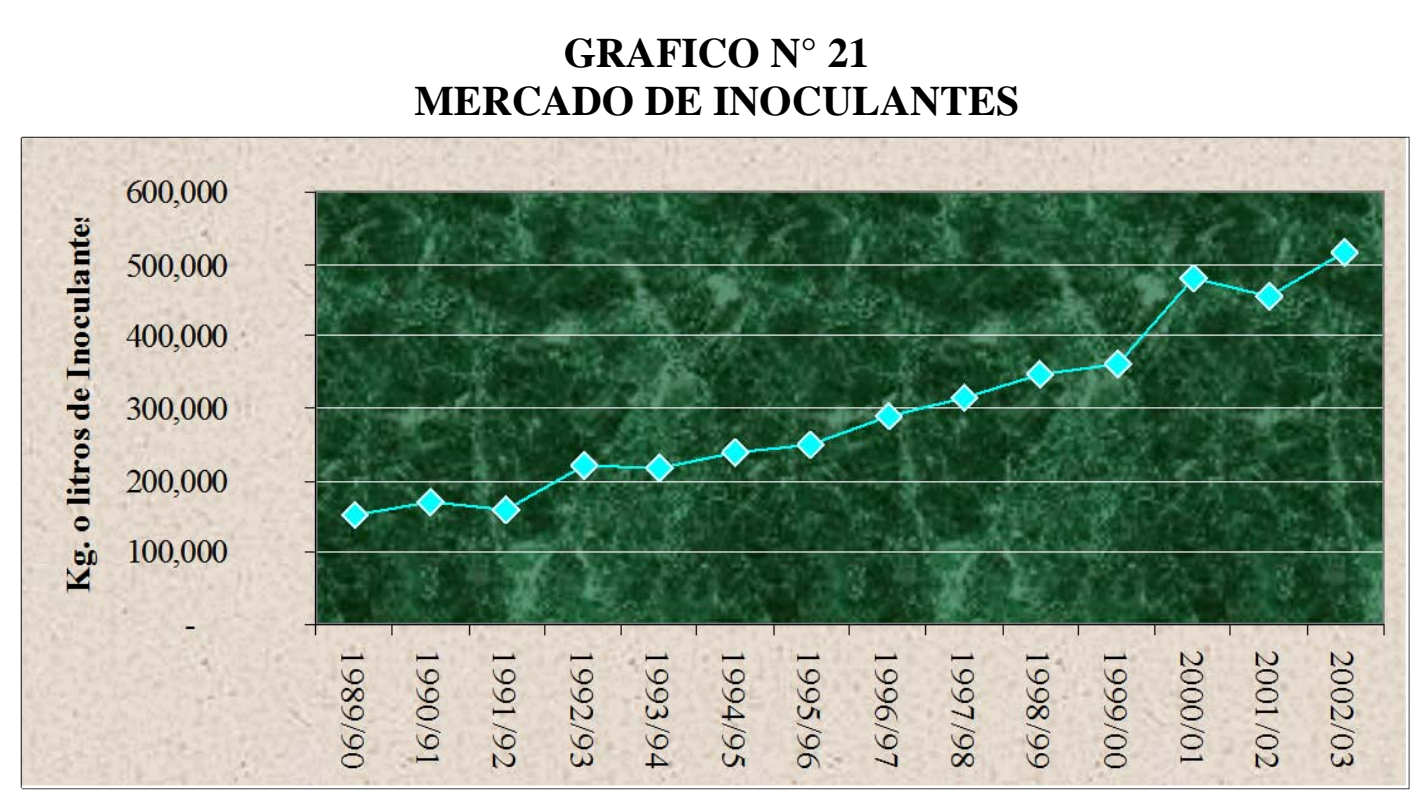

Fuente: elaboración propia en base a datos de SAGPyA y Márgenes Agropecuarios.

\subsection{Estimación de las ventas de la empresa}

En los últimos años, la cantidad de hectáreas sembradas de soja en nuestro país se ha ido incrementando continuamente. En base a un análisis retrospectivo y a datos suministrados por la SAGPyA es posible afirmar que dicho crecimiento operará en el futuro. Debido a ello, se realizaron estimaciones que suponen un aumento en el área 
sembrada de soja que varía entre el 5\% y 7\% anual según el año en cuestión. Estas proyecciones son realistas, dado que el crecimiento evidenciado en las hectáreas sembradas de soja durante el período 1989-2003 en el mercado objetivo alcanzan, en promedio un $6 \%$ anual.

A partir de dichas estimaciones y suponiendo un crecimiento también moderado de la proporción de áreas sembradas que utilizarán inoculantes en el futuro se obtiene un mercado proyectado como el mostrado en el siguiente cuadro.

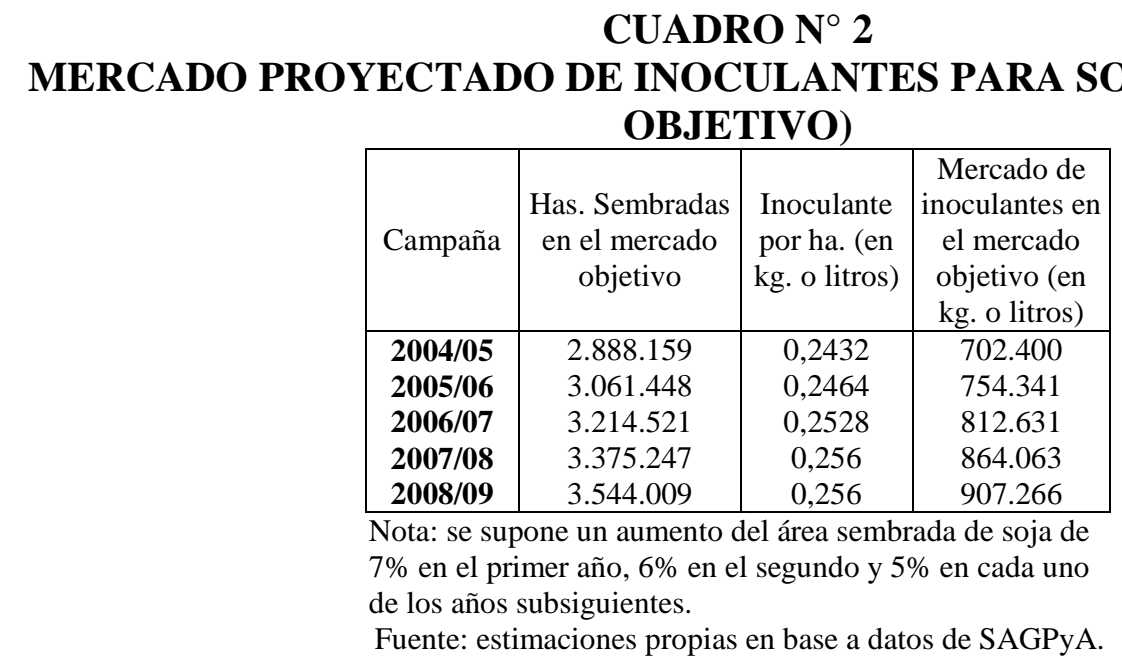

Hasta el momento se efectuó un análisis de mercado de inoculantes en el mercado objetivo. A partir de este momento se presentarán tres escenarios que muestren el volumen de ventas y la facturación que puede absorber la empresa en sus primeros años de operación.

Para ello se debe incluir una variable más en el análisis: el precio del inoculante. Dado que la mayor parte de los insumos agropecuarios están valuados en dólares, en adelante todas las cifras presentadas se referirán a la moneda estadounidense.

El precio del inoculante se ubica en torno a los U\$S 1,5 cada 200 g. o centímetro cúbico, es decir U\$S 7,5 el kg. o litro. Se supone que tenderá a la baja hasta ubicarse en \$ 1,2 al quinto año de operación de la firma, principalmente debido al avance tecnológico que se producirá en dicho período que permitirá reducir los costos de producción de este insumo agropecuario.

La participación de mercado estimada de la empresa para el primer año varía del $1 \%$ al 2,5\% según los distintos escenarios planteados: $1 \%$ en el escenario de mínima, $1,5 \%$ en uno moderado y $2,5 \%$ en un escenario de máxima; mientras que las tasas de crecimiento de la participación de mercado se mantiene en 0, 5 puntos porcentuales para cada uno de los escenarios. En el Cuadro que se presenta a continuación se presentan las estimaciones de mercado para los primeros cinco años de operaciones de la firma. 


\section{CUADRO $\mathbf{N}^{\circ} 3$}

ESTIMACIÓN DE LA PARTICIPACIÓN DE MERCADO DE LA EMPRESA

\begin{tabular}{|c|c|c|c|c|c|c|c|c|c|}
\hline & \multicolumn{3}{|c|}{ Escenario de mínima } & \multicolumn{3}{|c|}{ Escenario moderado } & \multicolumn{3}{|c|}{ Escenario de máxima } \\
\hline & $\begin{array}{l}\text { Participa- } \\
\text { ción de } \\
\text { mercado } \\
\end{array}$ & $\begin{array}{c}\text { Volumen } \\
\text { (en kg. o } \\
\text { litros) } \\
\end{array}$ & $\begin{array}{c}\text { Ventas (en } \\
\text { U\$S) }\end{array}$ & $\begin{array}{l}\text { Participa- } \\
\text { ción de } \\
\text { mercado } \\
\end{array}$ & $\begin{array}{c}\text { Volumen } \\
\text { (en kg. o } \\
\text { litros) } \\
\end{array}$ & $\begin{array}{c}\text { Ventas (en } \\
\text { U\$S) }\end{array}$ & $\begin{array}{l}\text { Participa- } \\
\text { ción de } \\
\text { mercado }\end{array}$ & $\begin{array}{c}\text { Volumen } \\
\text { (en kg. o } \\
\text { litros) } \\
\end{array}$ & $\begin{array}{c}\text { Ventas (en } \\
\text { U\$S) }\end{array}$ \\
\hline 2004/05 & $1,0 \%$ & 7.024 & 52.680 & $1,5 \%$ & 10.536 & 79.020 & $2,5 \%$ & 17.560 & 131.700 \\
\hline 2005/06 & $1,5 \%$ & 11.315 & 79.206 & $2,0 \%$ & 15.087 & 105.608 & $3,0 \%$ & 22.630 & 158.412 \\
\hline 2006/07 & $2,0 \%$ & 16.253 & 105.642 & $2,5 \%$ & 20.316 & 132.053 & $3,5 \%$ & 28.442 & 184.874 \\
\hline 2007/08 & $2,5 \%$ & 21.602 & 135.010 & $3,0 \%$ & 25.922 & 162.012 & $4,0 \%$ & 34.563 & 216.016 \\
\hline 2008/09 & $3,0 \%$ & 27.218 & 163.308 & $3,5 \%$ & 31.754 & 190.526 & $4,5 \%$ & 40.827 & 244.962 \\
\hline
\end{tabular}

Nota: se supone que el precio del inoculante es de U\$S 1,5 cada 200 gramos o centímetros cúbicos para el primer año, reduciéndose a U\$S 1,4; U\$S 1,3; U\$S 1,25 y U\$S 1,2, en los años subsiguientes.

Fuente: estimaciones propias en base a datos de SAGPyA.

La capacidad instalada actual de la firma permite producir alrededor de 12.000 litros de inoculantes por campaña. En el escenario de mínima, se supone que no se alcanzará ningún acuerdo con empresas dedicada a la venta de cereales y que la comercialización se realizará entre productores rurales de la zona a partir de las relaciones existentes entre uno de los socios y una gran cantidad de agroproductores.

Por su parte en el escenario moderado, se supone que existirá un acuerdo con una semillera de renombre por la cual se venderán más de 10.000 litros en el primer año (utilizando poco más del $80 \%$ de la capacidad instalada actual).

En el escenario de máxima, se supone que se venderá tanto a productores allegados como así también a una firma semillera. De este modo, la capacidad instalada actual no alcanzará para abastecer a la demanda por lo cual se requerirán inversiones adicionales para satisfacer a los consumidores.

Para los años siguientes se requerirá una ampliación de la capacidad instalada ya que se espera un aumento de la demanda que, excepto en el escenario de mínima, excederá la capacidad de producción de la firma. A medida que el proyecto lo requiera se espera una ampliación de la capacidad productiva y buscar nuevos mercados, hecho que no se descarta suceda en los primeros años de operación dadas las características particulares del sector en el que se requiere una continua adaptación a las condiciones de mercado dado su elevado componente tecnológico.

\section{FLUJO DE FONDOS DE AGROINVEST}

De acuerdo a las estimaciones de ventas para los primeros cinco años de operación del proyecto y suponiendo que se cumple el escenario moderado presentado anteriormente, en esta sección se elaborará el estado de resultados de la firma para sus primeros cinco años de vida, para luego estimar el flujo de fondos esperados y la tasa interna de retorno (TIR) del proyecto.

Además de suponer el escenario moderado de ventas, se considerarán las siguientes variables:

- Se considera que el $80 \%$ de las ventas se cobran en el mismo año en el que se concretaron. 
- Se efectúan importantes inversiones en investigación y desarrollo durante los primeros años, mientras que las erogaciones para el departamento de marketing son bajas en el primer año, debido a que estaría asegurada la venta de toda la producción potencial. Las inversiones en marketing se acrecienta a medida que se amplía la capacidad instalada.

- Dentro de servicios varios, se incluyen erogaciones en teléfonos, internet, papelería, etc.

- Se consideran los tres insumos necesarios para la producción y comercialización de inoculantes: turba, medios de cultivo y envases.

- La empresa invertirá 70.000 dólares durante el primer año de operación, U\$S 30.000 en el segundo y U\$S 20.000 en el tercero. Todas estas inversiones se destinarán a ampliación de la capacidad instalada y serán financiadas mediante tres préstamos en dólares a cinco años cada uno, pagando una tasa de 7\% anual. Así surgen los pagos de deuda de corto y largo plazo.

\section{CUADRO $\mathrm{N}^{\circ} 4$}

\section{ESTADO DE RESULTADOS DE AGROINVEST}

\begin{tabular}{|c|c|c|c|c|c|}
\hline$\longdiv { \text { Periodo } }$ & 1 & 2 & 3 & 4 & 5 \\
\hline Facturación & 79,020 & 105,608 & 132,053 & 162,012 & 190,526 \\
\hline Ingresos por ventas en el período & 63,216 & 84,486 & 105,642 & 129,610 & 152,421 \\
\hline Cuentas a cobrar & 15,804 & 21,122 & 26,411 & 32,402 & 38,105 \\
\hline \multicolumn{6}{|l|}{ Gastos Operativos } \\
\hline Investigación y Desarrollo & 8,000 & 6,000 & 8,000 & 8,500 & 9,000 \\
\hline Marketing & 2,000 & 5,000 & 10,000 & 10,000 & 10,000 \\
\hline Sevicios varios & 3,000 & 3,000 & 3,500 & 4,000 & 4,000 \\
\hline Energía & 1,500 & 1,750 & 1,850 & 1,900 & 2,000 \\
\hline Turba & 9,031 & 12,069 & 15,092 & 18,516 & 21,774 \\
\hline Medio de cultivo & 1,219 & 1,629 & 2,037 & 2,500 & 2,940 \\
\hline Envases & 6,800 & 9,088 & 11,364 & 13,942 & 16,396 \\
\hline Personal & 6,000 & 6,000 & 9,000 & 9,000 & 10,000 \\
\hline Total de Gastos Operativos & 37,550 & 44,537 & 60,843 & 68,357 & 76,109 \\
\hline Resultado Operativo & 41,470 & 61,071 & 71,210 & 93,655 & 114,417 \\
\hline Pago de deuda de corto plazo y largo plazo & 17,050 & 24,370 & 29,250 & 29,250 & 29,250 \\
\hline Resultado Financiero & 17,050 & 24,370 & 29,250 & 29,250 & 29,250 \\
\hline Depreciación & 7,000 & 10,000 & 12,000 & 12,000 & 12,000 \\
\hline Resultado Bruto & 17,420 & 26,701 & 29,960 & 52,405 & 73,167 \\
\hline Impuestos a las Ganancias & 6,097 & 9,345 & 10,486 & 18,342 & 25,608 \\
\hline Resultados después de Impuestos & 11,323 & 17,356 & 19,474 & 34,063 & 47,558 \\
\hline
\end{tabular}

Fuente: elaboración propia.

A partir del cuadro de resultados y suponiendo que la empresa pretende tener una caja mínima de una doceava parte de sus gastos operativos, un inventario en insumos (turba, medio de cultivo y envases) del 20\% de lo erogado anualmente y que se mantienen cuentas a pagar correspondientes al último bimestre de servicios varios y electricidad, se encuentra que el capital de trabajo de la firma se conforma de acuerdo a lo mostrado por el siguiente cuadro. 
CUADRO $\mathrm{N}^{\circ} 5$

CAPITAL DE TRABAJO DE AGROINVEST

\begin{tabular}{|l|ccccc|}
\hline & $\mathbf{1}$ & $\mathbf{2}$ & $\mathbf{3}$ & $\mathbf{4}$ & $\mathbf{5}$ \\
\hline Caja Mínima & 3129 & 3711 & 5070 & 5696 & 6342 \\
Inventario en Insumos & 3410 & 4557 & 5699 & 6991 & 8222 \\
Cuentas a Pagar & 750 & 792 & 892 & 983 & 1000 \\
& & & & & \\
Working capital & 5789 & 7477 & 9877 & 11705 & 13564 \\
Var de WC & 5789 & 1688 & 2400 & 1827 & 1860 \\
\hline
\end{tabular}

Fuente: elaboración propia.

A partir del análisis anterior es posible elaborar el flujo de fondos de AgroInvest para los primeros cinco años de operación.

\section{CUADRO $\mathrm{N}^{\circ} 6$}

FLUJO DE FONDOS DE AGROINVEST

\begin{tabular}{|l|cccccc|}
\hline \multicolumn{1}{|c|}{ Año } & $\mathbf{1}$ & $\mathbf{2}$ & $\mathbf{3}$ & $\mathbf{4}$ & $\mathbf{5}$ & $\mathbf{6}$ \\
\hline Resultado después de Impuestos & 11323 & 17356 & 19474 & 34063 & 47558 & \\
Amortizaciones & 7000 & 10000 & 12000 & 12000 & 12000 \\
Capital de Trabajo & 5789 & 1688 & 2400 & 1827 & 1860 & \\
Inversiones & 70000 & 30000 & 20000 & 0 & 0 & 63484 \\
Venta de Patrimonio Neto & & & & & & \\
& & & & & & \\
CASH FLOW & -45888 & -956 & 13874 & 47891 & 61418 \\
\hline
\end{tabular}

Fuente: elaboración propia.

A partir del cuadro anterior, puede apreciarse que durante los dos primeros años, la firma tendrá un flujo de fondos negativos pero que podrán ser financiados por los créditos obtenidos. A su vez, es posible observar que a partir del tercer año, AgroInvest comenzará a tener un flujo de fondos positivo que se acentuará notablemente durante los años siguientes.

Esta situación permitirá a la gerencia de la firma optar por repagar los créditos antes de tiempo o continuar con inversiones tendientes a aumentar la capacidad de producción, destinar más recursos a investigación y desarrollo, aumentar sus erogaciones en el departamento de marketing y/o mejorar los canales de distribución.

En cuanto a la viabilidad económica del proyecto, los números son contundentes ya que su tasa interna de retorno (TIR) es muy superior al costo de oportunidad del dinero de los accionistas. ${ }^{22}$

\section{CUADRO $\mathrm{N}^{\circ} 7$}

TASA INTERNA DE RETORNO DE AGROINVEST

\begin{tabular}{|ccccccc|}
\hline 0 & 1 & 2 & 3 & 4 & 5 & \\
1 & 1 & 1 & 1 & & & \\
& -45.888 & -956 & 13.874 & 47.891 & 61.418 & TIR $=34,1 \%$ \\
\hline
\end{tabular}

Fuente: elaboración propia.

\footnotetext{
${ }^{22} \mathrm{Al}$ momento de finalizarse este trabajo, los rendimientos a plazo fijo en dólares pagaban una tasa cercana al 3\% anual.
} 


\section{SITUACIÓN ACTUAL DE LA EMPRESA}

En su corta vida, Agroinvest ha basado su crecimiento en la constante innovación tecnológica apoyada en contactos permanentes con importantes centros de investigación a nivel internacional (EEUU, Canadá y Australia) y con los organismos nacionales que avalan la calidad de los productos comercializados por la firma (INTA y SENASA).

En la actualidad, comenzando el año 2011, los rasgos centrales que pueden remarcarse de la empresa son los siguientes:

$\checkmark$ Importante Capacidad Productiva: la planta de Agroinvest tiene una superficie cubierta de $900 \mathrm{~m} 2$. En el año 2008, inauguró su nueva planta de producción, con áreas de presión positiva, cumpliendo con todos los estándares de calidad para la elaboración de fertilizantes biológicos, permitiendo la producción de 4 millones de dosis de inoculantes por año. También se cuenta con la experiencia de haber producido en un plazo de 90 días la cantidad de 600.000 dosis de inoculante para soja en la campaña 2008-2009. Asimismo, dispone de un gran predio, que permitiría expandir la planta productiva en la medida que el mercado lo demande.

$\checkmark$ Innovación tecnológica constante: Agroinvest apunta a la innovación permanente y su planta productiva fue desarrollada íntegramente por los titulares de la firma con el consecuente "learning" generado que permitió incorporar nuevos insumos, tales como coadyuvantes e inoculantes para otros cultivos (maíz y trigo). Además se constituye en unas de las pocas firmas nacionales que se encuentran a la vanguardia de las innovaciones tecnológicas del sector con producción protocolizada y normatizada con GMP. También se cuentan con los conocimientos farmacotécnicos para ampliar la gama de productos a otras áreas como el peleteado.

$\checkmark$ Marcado crecimiento del sector en el que opera: la producción agrícola, principalmente el cultivo de soja viene experimentando un gran crecimiento en los últimos años. En la última década, el área sembrada de soja creció más de un 100\%, pasando de poco más de 8 millones de hectáreas en la campaña 1998-99 a cerca de 17 millones en la 2008-2009.

$\checkmark$ Reconocimiento del producto en el mercado local: a lo largo de los años, Fullbacter ha ido en constante crecimiento en la consideración de los productores agrícolas como así también en los principales distribuidores de agroinsumos. En este sentido, es destacable que el principal vendedor de inoculantes sin planta propia del país (Facyt SA) ha decidido adquirir a fasón Fullbacter y venderlo con marca propia en un segmento de inoculantes Premium, reconociendo los elevados estándares de calidad del producto. Por otra parte, la estación INTA Castelar (ente oficial y órgano rector en materia de innovación tecnológica en el agro argentino) valora la calidad del producto a partir de los controles que realiza. Todo esto ha posicionado a Fullbacter dentro de los inoculantes denominados Premium en Argentina.

$\checkmark$ Exportaciones: desde la campaña 2010-2011, la empresa está vendiendo su inoculante para soja Fullbacter en Paraguay y Bolivia. 
Registros obtenidos: Se obtuvieron los registros del SENASA para la producción de inoculante de soja, maíz y trigo como así también la línea de coadyuvantes de pulverización Full Touch (coadyuvante, corrector de PH, secuestrante de cationes y Full Touch Premium combinando los 3 efectos de los anteriores).

$\checkmark$ Ventajas impositivas: Agroinvest ha obtenido la exención en el pago del impuesto a los Ingresos Brutos de la provincia de Buenos Aires por estar exentos a dicho tributo los rubros comercializados por la empresa. Asimismo, no paga tasas municipales por estar radicado en un Parque Industrial.

$\checkmark$ Bajos costos de producción: la eficiencia productiva sumado a un tipo de cambio favorable permiten a la firma insertar sus productos en el exterior a precios muy competitivos.

$\checkmark$ Fuerza de ventas a desarrollar: hasta el momento se concentraron los esfuerzos en aumentar la capacidad productiva y en desarrollar un producto de excelencia, objetivo cumplido con creces. El desarrollo de nuevos canales de ventas y la inversión en publicidad permitirían aumentar considerablemente las ventas.

Dadas las ventajas que se enumeraron hasta aquí, Agroinvest cuenta con un alto potencial de crecimiento. Asimismo, existen algunos tópicos que pueden remarcarse para la estimación de las ventas para los próximos 3 años:

Tratativas con importadores de agroinsumos de Brasil: se han iniciado contactos con varios distribuidores de agroinsumos en Brasil, y uno de ellos ha mostrado un marcado interés en comenzar a adquirir inoculantes para soja.

$\checkmark$ Tratativas con broker con presencia en China: un broker con participación en el mercado chino se ha acercado a la empresa con el objetivo de introducir inoculantes para soja en el país asiático.

Como corolario, a continuación se presenta la evolución de las ventas de la empresa en los últimos años, notándose un importante crecimiento hasta el año 2007 con una caída en 2008 y una importante recuperación en los años 2009 y 2010.

\section{GRAFICO $\mathrm{N}^{\circ} 22$}

VENTAS ANUALES DE LA EMPRESA

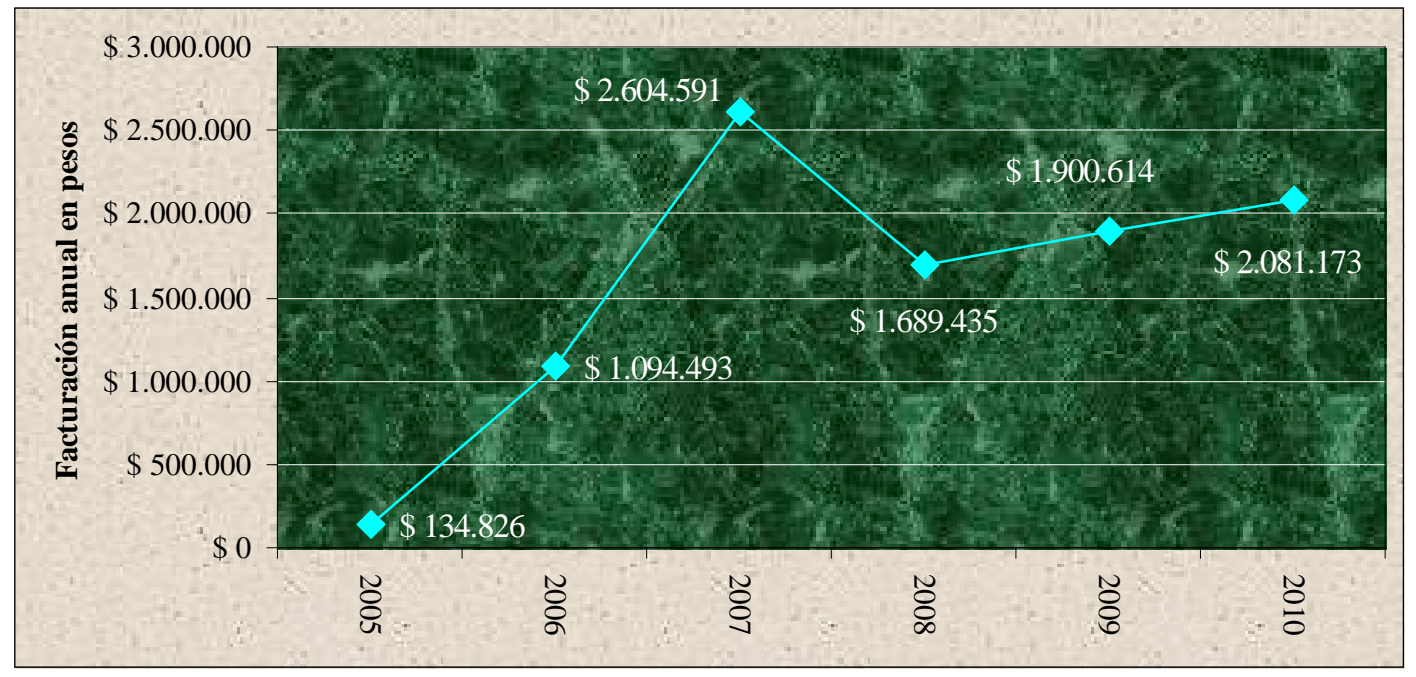

Fuente: elaboración propia con datos provistos por la empresa. 
Del gráfico anterior se desprende que desde el año 2005, primer ejercicio formal de la empresa, las ventas anuales siempre fueron muy superiores a las estimaciones en el Capítulo anterior. La excelente performance la firma en su corta existencia ha motivado el interés de varias firmas de capital extranjero para participar como socios como así también se han recibido importantes ofertas de compra que hasta el momento de la finalización de este trabajo no han sido aceptadas por sus titulares.

\section{BIBLIOGRAFÍA}

\section{$\underline{\text { Libros }}$}

Araujo (2001): “A inoculação de leguminosas. Aumento da produtividade com a fixação biológica de nitrogênio”.

Andreasen A. Y Belk R.: "Predictors of Attendance at the Performing Arts. Journal of Consumer Resarch, citado en Kotler. Septiembre. 1980

Campana E., Gómez Sánchez F. (2000): "Principios de mercadotecnia”. Editorial Universitaria de La Plata.

Cuaderno de Economía No 64 (2002). “Clusters productivos en la provincia de Buenos Aires. Segunda parte”.

Gutman G. (2000): “Trayectorias y demandas tecnológicas de las cadenas agroindustriales en el MERCOSUR ampliado -Oleaginosas: Soja y Girasol”, PROCISUR, BID, Serie Documentos N³, Montevideo, Abril.

Kotler P.: "Dirección de la Mercadotecnia. Análisis, Planeación, Implementación y Control”. Prentice-Hall Hispanoamericana. Séptima Edición.

Kotler P.: “Gerencia de comercialización”, (Prentice-Pasillo, 7mo ed., 1991).

Levitt, Theodore (1981). «El ciclo de vida del producto: gran oportunidad de marketing». Harvard-Deusto Business Review ( $2^{\circ}$ trimestre): p. 5-28.

Porter, M. (1990); “The Competitive Advantage of Nations”, New York: Basic Books.

Reeves R.: “Reality in Advertising”. Nueva York: Knopf, citado en Kotler. 1960.

\section{Citas web}

Clancy K. (2002): “El poder de la visión de marketing”. Extraído de http://www.copernicusmarketing.com/copernicus-

es/articulos/vision_de_marketing.htm.

Food and Agriculture Organization (FAO), página web: http://www.fao.org.

Secretaría de Agricultura Ganadería, Pesca y Alimentación (SAGPyA), página web: http://sagpya.gov.ar.

Dirección Provincial de Estadística, página web: http://www.ec.gba.gov.ar/Estadistica/FTP/index.htm.

Laboratorios Biagro S.A, página web: http://www.biagrosa.com.

Rizobacter Argentina S.A, página web: http://www.rizobacter.com.ar.

Buscagro, publicaciones varias, en su página web: http://www.buscagro.com. 
Via Rural, publicaciones varias, en su página web: http://www.viarural.com.ar.

E-Campo, publicaciones varias, en su página web: http://e-campo.com.ar.

Revista Márgenes Agropecuarios, varios números.

Revista Estrategia Marketing. Ver http://www.estrategiamagazine.com/tags/kennethandrews/

Nitragin S.A, página web: http://www.nitragin.com.ar.

Barenbrug-Palaversich S.A, página web: http://www.barenbrug.com.ar.

Estrategia Magazine, página web: http://www.estrategiamagazine.com.ar.

\section{Otras fuentes}

Encuesta realizada los días 13, 14, 15 y 16 de marzo de 2003 entre productores que asistieron a la megaexposición agropecuaria FeriaAgro.

Reuniones mantenidas con los gerentes de la empresa Agroinvest (entre 2003 y 2011). 


\section{ANEXO}

\section{Encuesta a productores agropecuarios sobre inoculantes}

1. Nombre y apellido:

2. E-mail y/o Teléfono:

3. ¿En qué municipio/s ha sembrado soja en la última campaña?

4. ¿Cuántas hectáreas de soja ha sembrado en su última campaña?
$\square$ Menos de 100
Entre 100 y 300
Entre 300 y 700
$\square$ Más de 700

5. ¿Qué tipo de inoculante para soja utiliza?

$\square$ Líquido con funguicida y/o curasemilla $\square$ Líq. sin fungicida $\square$ Polvo $\square$ Otro

Si su respuesta anterior fue Otro, por favor especifique:

¿En qué tipo de envase recibe el inoculante?

$\square$ Sachets $\square$ Bolsas $\square$ Packs de sachets o de bolsas $\square$ Otro

Si su respuesta anterior fue Otro, por favor especifique:

6. ¿Qué cantidad de inoculante contiene cada envase? $\square 150$ gramos $\square 250$ gramos $\square 400$ cc. $\square$ Mayor cantidad $\square$ No recuerda

7. ¿Qué marca de inoculante para soja utilizó en su anterior campaña?

8. ¿Cuántos años hace que utiliza esa marca de inoculante? 
9. ¿Estaría dispuesto a probar un nuevo inoculante que no está actualmente en el mercado?<smiles>[SiH3]C1CCC1</smiles>

10. ¿Qué atributo valora cuando adquiere un inoculante?

$\square$ Precio $\square$ Servicio de pre y post venta $\square$ Tamaño del envase $\square$ Otras

Si su respuesta anterior fue Otras, por favor especifique:

11. ¿A través de quién adquiere el inoculante?

Directamente en la empresa fabricante $\square$ Representantes exclusivos de la empresa Distribuidores de todo tipo de insumos agropecuarios $\square$ Otra alternativa Si su respuesta anterior fue Otra alternativa, por favor especifique:

12. ¿Cómo conoció el inoculante que utiliza actualmente?

A través de un productor amigo

Folletos de la empresa enviados por distribuidores

$\square$ Publicidad en revistas especializadas

A través del INTA

Por favor, especifique el medio de comunicación (por ejemplo Radio Continental, Canal Rural, Márgenes Agropecuarios, etc.)

Muchas gracias por su colaboración. La información obtenida redundará en beneficios para todos. 


\section{Aclaración:}

“Declaro bajo juramento que esta Tesis fue elaborada por mí, que no utilicé ningún otro material que no haya dado a conocer en las referencias y que no utilicé frases o párrafos de otros autores, que este trabajo de Tesis nunca ha sido presentado ante un Comité de Evaluación de Tesis y que no transgredí derechos de terceros”. 
UNIVERSIDAD NACIONAL DE LA PLATA

Facultad de Ciencias Económicas

Escuela de Postgrado en Marketing Internacional

Magister en Marketing Internacional 